\title{
Host-Directed Therapeutic Strategies for Tuberculosis
}

\author{
Afsal Kolloli and Selvakumar Subbian* \\ Public Health Research Institute (PHRI) at New Jersey Medical School, Rutgers Biomedical and Health Sciences (RBHS), \\ Rutgers University, The State University of New Jersey, Newark, NJ, United States
}

Tuberculosis (TB), caused by Mycobacterium tuberculosis (Mtb), remains a leading cause of morbidity and mortality in humans worldwide. Currently, the standard treatment for TB involves multiple antibiotics administered for at least 6 months. Although multiple antibiotics therapy is necessary to prevent the development of drug resistance, the prolonged duration of treatment, combined with toxicity of drugs, contributes to patient non-compliance that can leads to the development of drug-resistant Mtb (MDR and XDR) strains. The existence of comorbid conditions, including HIV infection, not only complicates TB treatment but also elevates the mortality rate of patients. These facts underscore the need for the development of new and/or improved TB treatment strategies. Host-directed therapy (HDT) is a new and emerging concept in the treatment of TB, where host response is modulated by treatment with small molecules, with or without adjunct antibiotics, to achieve better control of TB. Unlike antibiotics, HDT drugs act by directly modulating host cell functions; therefore, development of drug resistance by infecting Mtb is avoided. Thus, HDT is a promising treatment strategy for the management of MDR- and XDR-TB cases as well as for patients with existing chronic, comorbid conditions such as HIV infection or diabetes. Functionally, HDT drugs fine-tune the antimicrobial activities of host immune cells and limit inflammation and tissue damage associated with TB. However, current knowledge and clinical evidence is insufficient to implement HDT molecules as a stand-alone, without adjunct antibiotics, therapeutic modality to treat any form of TB in humans. In this review, we discuss the recent findings on small molecule HDT agents that target autophagy, vitamin D pathway, and anti-inflammatory response as adjunctive agents along with standard antibiotics for TB therapy. Data from recent publications show that this approach has the potential to improve clinical outcome and can help to reduce treatment duration. Thus, HDT can contribute to global TB control programs by potentially increasing the efficiency of anti-TB treatment.

Keywords: tuberculosis, autophagy, host-pathogen interactions, vitamin D, anti-tuberculosis drugs, infant, adjunct therapy-tuberculosis

\section{INTRODUCTION}

Tuberculosis (TB) continues to be a major health threat, particularly in developing countries. In 2015, about 10.4 million new cases and 1.4 million deaths were attributed to TB worldwide (1). In addition, nearly a third of the world population is believed to carry latent Mycobacterium tuberculosis (Mtb) infection (LTBI) (2). Out of the billions of people with LTBI, about $10 \%$ will 
develop symptomatic, active TB during their lifetime. Thus, these LTBI individuals are a reservoir for potential future active TB cases. The morbidity and mortality due to TB are further accelerated by coinfection with HIV, development of drug-resistant $M t b$ strains, and coexistence of other chronic illness such as diabetes (3-5).

The current TB treatment regimen, implemented by the WHO includes administration of four first-line antibiotics isoniazid (INH), rifampicin (RIF), pyrazinamide (PZA), and ethambutol for 2 months followed by INH and RIF for 4 months. Since $M t b$ can develop resistance more rapidly to individual drugs, a standard TB therapy [directly observed treatment, shortcourse (DOTs)] with a combination of these four drugs was established in the 1980s. Since then, DOTs have been shown to be effective in achieving microbiological cure in patients with drug-sensitive TB. Although successful compliance of DOTs should not contribute to the emergence of drug resistant $M t b$ strains in these patients, incorrect drug prescription/treatment and patient non-compliance can lead to $M t b$ drug resistance, mostly to INH and RIF, two of the most important/potent first line drugs, resulting in the development of MDR- and XDR-TB cases. Recent epidemiological data have revealed nearly halfmillion newly diagnosed MDR cases and an additional 100,000 of RIF-mono-resistant TB cases worldwide; about $10 \%$ of MDR cases were also found to have XDR (1). The prolonged and complicated anti-TB chemotherapy for MDR- and XDR-cases is not only expensive and not sufficiently effective in achieving the cure but also causes adverse, toxic side effects, challenging patient compliance to treatment. These dire limitations emphasize the need for new treatment and management strategies for both drug-sensitive and drug-resistant TB. In this review article, we discuss the various host-directed therapeutic (HDT) approaches that have gained considerable research interest as an adjunct to antibiotic-based anti-TB treatments.

\section{IMMUNE RESPONSE IN TB}

Tuberculosis is transmitted through inhalation of $M t b$-containing aerosol; in about $95 \%$ of cases, wherein the tubercle bacilli was inhaled, a primary infection is established. However, progressive, active TB is successfully prevented in $>90 \%$ of these individuals by the host immune response, resulting in latent $M t b$ infection (LTBI) with no visible symptom of active disease. Individuals with LTBI have 5-10\% lifetime risk of developing active TB and host immune suppressing conditions further increases this risk. This underscores the critical role of host innate and adaptive immune response in the control of $M t b$ infection (6). The host immunity to infection is initiated following the uptake of $M t b$ by phagocytes, such as alveolar macrophages and dendritic cells (DCs), in the lower respiratory tract. The interaction between phagocyte pattern recognition receptors and $M t b$ antigens triggers the production of various proinflammatory cytokines, including tumor necrosis factor- $\alpha$ (TNF- $\alpha$ ) and interleukin-12 (IL-12) as well as chemokines that recruit and activate other innate and adaptive immune cells from the circulation to the site of infection (7-9). The accumulation of various immune cell types surrounding the infected phagocytes, in response to secreted cytokines and chemokines, results in the formation of granulomas, a hallmark of $M t b$ infection. Although granulomas have been thought to act as a physiological barrier in preventing dissemination of infection and providing a microenvironment that facilitates the interaction between the immune cells and the pathogen, it can also serve as a niche where $M t b$ can thrive and persist (10-12). The fate of intracellular $M t b$ within the phagocytes is determined by various cellular processes, including apoptosis, autophagy, and activation of host defense pathways that produce antimicrobial peptides and reactive oxygen/ nitrogen species (13-15). These biological functions of activated macrophages and DCs are capable of killing $M t b$; however, it is well documented that virulent $M t b$ can prevent the fusion and acidification of phagolysosomal compartments, which are crucial for $M t b$ killing, thus evading the host immune response to survive within these cells (16-18).

While innate immune mechanisms are mostly insufficient to prevent $M t b$ infection from progressing into active disease, phagocytes such as DCs with engulfed $M t b$ and/or antigens can migrate to the regional lymph nodes to prime CD4+ and CD8+ $\mathrm{T}$ cells. These activated cells of adaptive immunity establish a Th1 type immune response, marked by induction of interferon- $\gamma$ (IFN- $\gamma$ ) secretion, which can activate antimicrobial functions and apoptosis of infected macrophages through Fas/Fas ligand interaction (19). In these cells, IFN- $\gamma$ also enhances the recruitment of CD4+ and cytotoxic T lymphocytes to the site of infection, thus promoting antigen presentation and mycobacterial killing by phagocytes $(20,21)$.

The Th1 immune response to $M t b$ infection is further enhanced by IL-17, a Th17-type cytokine that enhances the secretion of IFN- $\gamma$ and IL-12 from antigen presenting cells (22). Moreover, natural killer (NK) cells, NK T cells, and CD8+ T cells secrete an array of cytotoxic effector molecules, such as perforin, granulysin, and granzymes that can kill intracellular bacteria by lysing (necrosis) the infected cells (23). However, the elevated production of proinflammatory cytokines, such as TNF- $\alpha$, IL-1 $\beta$, IL- 6 , IL- 8 , and IFN- $\alpha / \beta$, and the cytolytic-T cell response can also cause overt lung inflammation and tissue damage during $M t b$ infection (24-27). This dual effect of host immune activation highlights the need for an HDT treatment strategy that can alleviate host tissue/cell damage by regulating the inflammatory response, while enhancing the anti- $M t b$ defense mechanisms, to improve treatment outcomes. Recent studies have shown that $M t b$ growth can be restricted by modulating several host immune cell functions $(28,29)$ (Figure 1). This information can be harnessed to develop new treatment strategies against both drug-sensitive and MDR/XDR-TB cases.

On the other hand, HDT strategies that modulate and/or suppress the natural host immune response against $M t b$ infection bears a risk of elevating the proportion of LTBI individuals to reactivate, or accelerate the progression of, TB disease. It has been shown that neutralization of TNF- $\alpha$ led to the reactivation of TB in individuals with LTBI (30) and promote the disease progression to fulminant and disseminated disease (9). Similarly, in the absence of standard anti-TB therapy, administration of anti-TNF- $\alpha$ antibodies exacerbates disease severity in a mouse model of pulmonary TB $(31,32)$. This possibility 

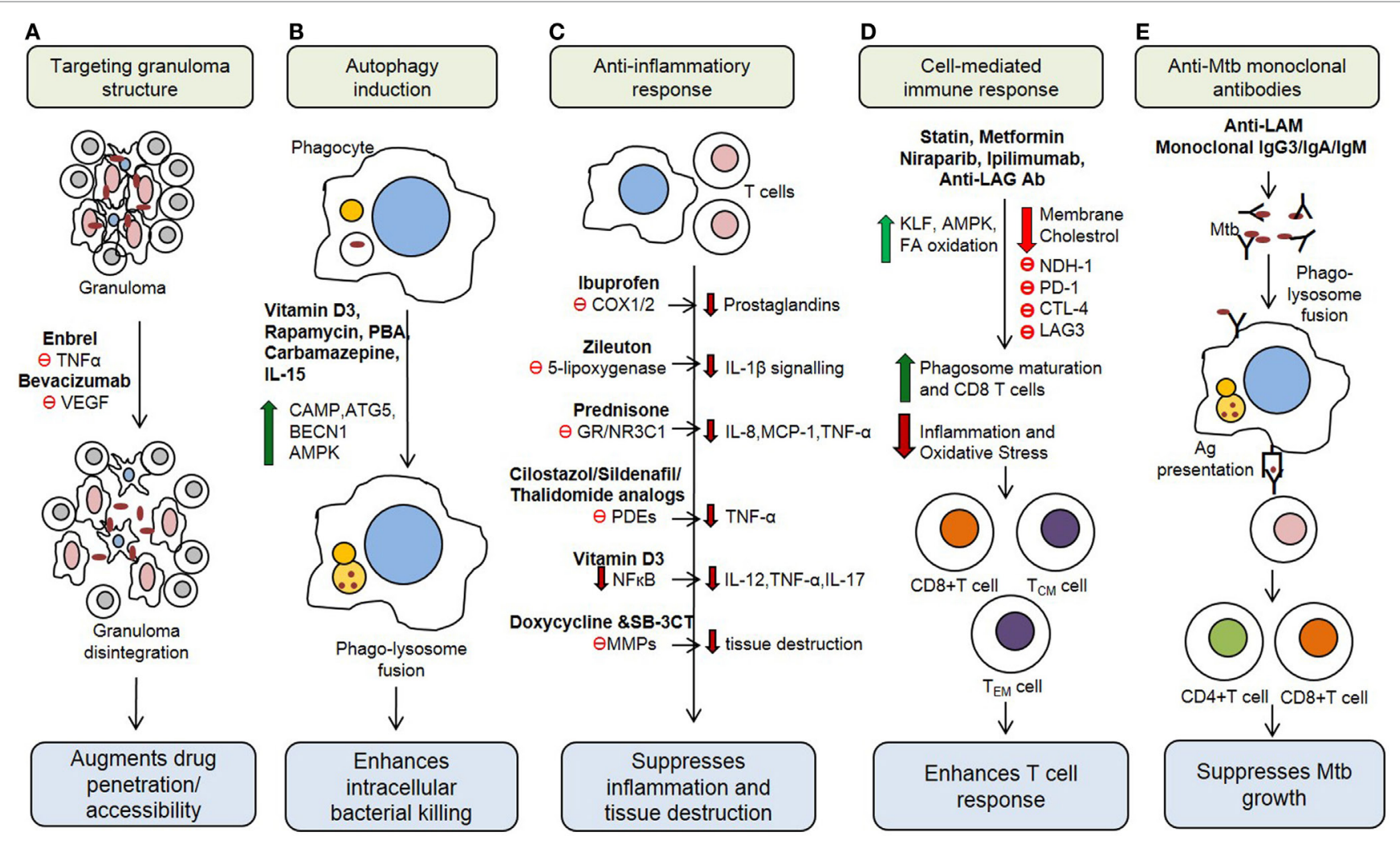

FIGURE 1 | Potential host therapeutic targets against Mycobacterium tuberculosis. (A) Host-directed therapeutic (HDT) drugs change the integrity of granuloma and enhance drug accessibility. (B) Some HDT agents upregulate production of antimicrobial peptides, reactive oxygen and induce autophagy in infected cells. (C) HDT drugs suppress proinflammatory responses, which decrease inflammation and tissue damage during active stage of the disease. (D) HDT agents regulate cell-mediated immune responses, including antigen-specific T cell responses. (E) Monoclonal antibody administration IS other emerging HDT concept for TB treatment. VEGF, vascular endothelial growth factor; PBA, phenylbutyrate; CAMP, cathelicidin antimicrobial peptide; ATG5, autophagy-related protein 5; BECN1, beclin-1; AMPK, AMP-activated protein kinase; COX1/2, cyclooxygenase-1/2; GR, glucocorticoid receptor; PDE, phosphodiesterases; MMPs, matrix metalloproteinases; KLF, Kruppel-like factor; PD-1, programmed cell death 1 receptor; CTLA-4, cytotoxic T-lymphocyte-associated protein 4; LAG3, lymphocyte activation gene 3; LAM, Lipoarabinomannan.

cautions the application of HDT as a sole approach for TB treatment and justifies the use of HDT as adjunctive to anti-TB drugs. This review is mainly focused on the adjunctive effect of various HDT agents that modulate various aspects of the immune response, including the production of reactive oxygen species, antimicrobial peptide synthesis, cytokine production, autophagy induction, development of cell-mediated immunity, and boosting immunological memory against $M t b$ infection (Table 1). It should be noted that most, if not all, of the HDTs that have been evaluated as a potential therapy for TB in animal models or humans, as mentioned in the following sections, were administered in combination with existing antimycobacterial antibiotics, as an adjunctive therapy.

\section{HDT TARGETING GRANULOMA FORMATION}

Tumor necrosis factor- $\alpha$ plays a significant role in the granuloma formation and maintenance of its integrity (78). However, granulomas can restrict the access of antibiotics to the $M t b$ contained in granuloma centers $(79,80)$, prolonging anti-TB treatment. Neutralization of TNF- $\alpha$ using anti-TNF- $\alpha$ antibody (Enbrel) during $M t b$ infection leads to disruption of granuloma integrity, which augments the bacterial clearance by antibiotic treatment and reduces lung pathology (33) (Table 1; Figure 1). Similarly, a clinical trial has shown the blocking of TNF using etanercept during the initial stage of $\mathrm{TB}$ treatment accelerated sputum culture conversion with $25 \%$ increase in CD4 cells in HIV-associated TB (81). However, anti-TNF- $\alpha$ antibodies can also suppress host immunity, exacerbating disease severity, as shown in animal models $(33,81)$.

Granulomas are also characterized by increased expression of vascular endothelial growth factor (VEGF) and angiopoietins (Angs) that promote abnormal angiogenesis and a hypoxic microenvironment (34). Earlier studies have shown an increased level of VEGF-A, VEGF-C, Ang-1, and Ang-2 in pulmonary TB patients as compared to healthy controls $(82,83)$. Antibody neutralization of VEGF (bevacizumab) or treatment with SU5416 (tyrosine kinase receptor inhibitor), and pazopanib (VEGFR inhibitor) enhanced the efficacy of anti-TB drugs by normalizing the vascular structure and reducing hypoxia; these 
TABLE 1 | List of host-directed therapeutic agents and their application in tuberculosis treatment.

\begin{tabular}{|c|c|c|c|}
\hline HDT agent & Mechanism of action & Biological significance & Selected reference \\
\hline Enbrel & TNF- $\alpha$ neutralization & Disrupts granuloma and reduces lung pathology & Bourigault et al. (33) \\
\hline Bevacizumab & Neutralizes VGEF & $\begin{array}{l}\text { Normalize the vascular structure, decreases the hypoxia, } \\
\text { and facilitates the entry of drug in the granuloma }\end{array}$ & $\begin{array}{l}\text { Oehlers et al. (34), } \\
\text { Datta et al. (35) }\end{array}$ \\
\hline \multirow[t]{4}{*}{ Vitamin $D_{3}$} & $\begin{array}{l}\text { Induces the production of reactive oxygen and } \\
\text { nitrogen intermediates, CAMP and DEFB4 }\end{array}$ & Enhance innate immune responses & $\begin{array}{l}\text { Liu et al. (36, 37), Yuk et al. } \\
\text { (38), Verway et al. (39) }\end{array}$ \\
\hline & $\begin{array}{l}\text { Upregulates the expression of Atg5 and } \\
\text { Beclin-1 }\end{array}$ & Induces autophagy of infected cells & Campbell and Spector (40) \\
\hline & $\begin{array}{l}\text { Suppresses NF-кB signaling pathways, } \\
\text { expression of MMPs proinflammatory cytokines } \\
\text { and chemokines }\end{array}$ & $\begin{array}{l}\text { Accelerates the resolution of inflammatory responses during } \\
\text { the treatment }\end{array}$ & $\begin{array}{l}\text { Coussens et al. (41), Coussens } \\
\text { et al. (42), Song et al. (43) }\end{array}$ \\
\hline & $\begin{array}{l}\text { Downregulates MHC class II molecules and } \\
\text { impairs the CD4 T cell activation, suppresses } \\
\text { proliferation of cytotoxic cells, enhance } \\
\text { differentiation regulatory T cells }\end{array}$ & $\begin{array}{l}\text { Reduces inflammation and tissue injury caused by } \\
\text { exacerbated production of cytotoxic molecules }\end{array}$ & $\begin{array}{l}\text { Imazeki et al. (44), Jeffery } \\
\text { et al. (45), Baeke et al. (46), } \\
\text { Harishankar et al. (47) }\end{array}$ \\
\hline Phenylbutyrate & $\begin{array}{l}\text { Histone deacetylases inhibitor, Induces } \\
\text { expression of CAMP, Atg5, and Beclin-1 } \\
\text { production of reactive oxygen species }\end{array}$ & $\begin{array}{l}\text { Promotes colocalization of LL-37 and LC3-II in } \\
\text { autophagosomes and restricts } M \text {. tuberculosis growth } \\
\text { inside the macrophage }\end{array}$ & $\begin{array}{l}\text { van der Does et al. (48), } \\
\text { Coussens et al. (49), } \\
\text { Rekha et al. (50) }\end{array}$ \\
\hline Rapamycin & Inhibits mTOR & Induces autophagy & Corcelle et al. (51) \\
\hline Gefitinib & Inhibits EGFR & $\begin{array}{l}\text { Activates autophagy and decreases in } M \text {. tuberculosis } \\
\text { growth inside the macrophage }\end{array}$ & Stanley et al. (52) \\
\hline Carbamazepine & $\begin{array}{l}\text { Depletes inositol triphosphate and activates } \\
\text { AMPK }\end{array}$ & $\begin{array}{l}\text { Induces autophagy and reduces MDR-TB burden } \\
\text { in the lungs and spleen }\end{array}$ & Schiebler et al. (53) \\
\hline Aspirin & Enhance the LXA4 production & Activates vitamin D-mediated anti-mycobacterial activities & $\begin{array}{l}\text { Tobin et al. (54), } \\
\text { Morris et al. (55) }\end{array}$ \\
\hline Ibuprofen & $\begin{array}{l}\text { Inhibits COX1 and COX2, suppresses } \\
\text { prostaglandin } \mathrm{H} 2 \text { production }\end{array}$ & $\begin{array}{l}\text { Regulates TNF- } \alpha \text { production and reduces inflammatory } \\
\text { pathology }\end{array}$ & Vilaplana et al. (56) \\
\hline Zileuton & Inhibits 5-lipoxygenase & $\begin{array}{l}\text { Suppresses the production of leukotrienes, augments } \\
\text { prostaglandin E2, reduces lung pathology }\end{array}$ & Mayer-Barber et al. (57) \\
\hline $\begin{array}{l}\text { Prednisone and } \\
\text { dexamethasone }\end{array}$ & Glucocorticoid receptor antagonist & Downregulates production of proinflammatory cytokines & $\begin{array}{l}\text { Blum et al. (58), } \\
\text { Bilaceroglu et al. (59) }\end{array}$ \\
\hline $\begin{array}{l}\text { CC-3052, CC-11050, } \\
\text { cilostazol, and } \\
\text { sildenafil }\end{array}$ & PDE inhibitors, increase the cAMP levels & Downregulate TNF- $\alpha$ level, inflammation, and lung necrosis & $\begin{array}{l}\text { Koo et al. (31), Subbian } \\
\text { et al. (60), Maiga et al. (61) }\end{array}$ \\
\hline Doxycycline, SB-3CT & Inhibits the expression of MMPs & Reduces the bacterial load in the lung & $\begin{array}{l}\text { Walker et al. (62), } \\
\text { Majeed et al. (63) }\end{array}$ \\
\hline \multirow[t]{2}{*}{$\begin{array}{l}\text { Statin (e.g., } \\
\text { simvastatin) }\end{array}$} & $\begin{array}{l}\text { Downregulates production proinflammatory } \\
\text { cytokines }\end{array}$ & Suppresses inflammation and tissue damage & Jain and Ridker (64) \\
\hline & $\begin{array}{l}\text { Decrease in the membrane } \\
\text { cholesterol levels }\end{array}$ & $\begin{array}{l}\text { Promotes phagosomal maturation and autophagy, } \\
\text { augments tuberculocidal activity of first-line drugs }\end{array}$ & $\begin{array}{l}\text { Parihar et al. (65), } \\
\text { Skerry et al. (66) }\end{array}$ \\
\hline Niraparib & $\begin{array}{l}\text { Inhibits poly(ADP-ribose) polymerase, induces } \\
\text { the mitochondrial fatty acid oxidation }\end{array}$ & $\begin{array}{l}\text { Removes oxidative stress, maintain memory CD8 T cell } \\
\text { responses and promotes cell-mediated immunity }\end{array}$ & Pirinen et al. (67) \\
\hline Resveratrol & $\begin{array}{l}\text { Increases the respiratory capacity } \\
\text { and regulatory } T \text { cell frequency }\end{array}$ & Reduces oxidative stress and regulates severe inflammation & $\begin{array}{l}\text { Beeson et al. (68), } \\
\text { Wang et al. (69) }\end{array}$ \\
\hline $\begin{array}{l}\text { Nivolumab/ } \\
\text { pembrolizumab }\end{array}$ & Inhibits the expression of PD-1 & $\begin{array}{l}\text { Augments CD8+ T cell-mediated immune } \\
\text { response }\end{array}$ & $\begin{array}{l}\text { Gros et al. (70), } \\
\text { Borch et al. (71) }\end{array}$ \\
\hline $\begin{array}{l}\text { Infusion of } \\
\text { mesenchymal } \\
\text { stromal cells }\end{array}$ & $\begin{array}{l}\text { Enhances antigen specific } T \text { cells } \\
\text { and dendritic cell immune response }\end{array}$ & Facilitate organ homeostasis and tissue repair & $\begin{array}{l}\text { Skrahin et al. (72), } \\
\text { Joshi et al. (73) }\end{array}$ \\
\hline $\begin{array}{l}\text { Adoptive transfer of } \\
\text { antigen-specific } \\
\text { T cells }\end{array}$ & Targeted killing of infected cells & Restrict the growth and replication of intra cellular pathogen & $\begin{array}{l}\text { Axelsson-Robertson } \\
\text { et al. (74) }\end{array}$ \\
\hline $\begin{array}{l}\text { Supplementation of } \\
\text { nebulized IFN- } \gamma\end{array}$ & Increases in CD4+ T cell response & $\begin{array}{l}\text { Improves response to treatment in cavitary } \\
\text { TB patients }\end{array}$ & Dawson et al. (75) \\
\hline $\begin{array}{l}\text { Antituberculin } \\
\text { antibodies-lgG3/mlgA }\end{array}$ & Reduces pathogenecity of $M$. tuberculosis & $\begin{array}{l}\text { Prevent reactivation of TB and decrease bacterial load in } \\
\text { the lung }\end{array}$ & $\begin{array}{l}\text { Encinales et al. (76), } \\
\text { Balu et al. (77) }\end{array}$ \\
\hline
\end{tabular}


morphological changes facilitated improved anti-TB drug penetration and killing of $M t b$ in the granuloma $(34,35)$ (Table 1; Figure 1). Together, these studies suggest that granuloma integrity is a critical factor for bacterial survival and proliferation and that disruption of granulomas may promote drug penetration. Thus, a combination of HDT and anti-TB drugs should help to improve the efficacy and clinical outcome as well as to shorten the duration of treatment.

\section{HDT TARGETING THE VITAMIN D PATHWAY TO MODULATE IMMUNE RESPONSE}

Immunomodulators such as 1,25-dihydroxyvitamin $\mathrm{D}_{3}[1,25$ $(\mathrm{OH})_{2} \mathrm{D}_{3}$ ] that upregulate the innate immune functions and regulate inflammatory responses have attracted considerable research interest as $\mathrm{HDT}$ for TB (84). $1,25(\mathrm{OH})_{2} \mathrm{D}_{3}$ has been shown to induce the production of reactive oxygen and nitrogen intermediates, antimicrobial peptides such as cathelicidin antimicrobial peptide (CAMP) and beta-defensin-4 (DEFB4), whereas it limits iron availability for intracellular bacteria and inhibits the accumulation of lipid droplets in $M t b$-infected macrophages (36-39, 85-90). Although these studies are promising, clinical trials on vitamin D supplementation therapy revealed contrasting results [(91-93); see below].

The $M t b$-killing activity of macrophages can be enhanced by a combination of modulating the vitamin $\mathrm{D}$ pathway and inhibiting the activity of histone deacetylases (HDACs) (94). HDACs are a group of enzymes that remove acetyl groups from histones; inhibition of HDACs typically promotes gene transcription (95). Phenylbutyrate (PBA) is an HDAC inhibitor, which induces CAMP/LL-37 gene expression in cell lines and suggested to have a role in the treatment of $M t b$ infection (96). Administration of PBA (500 mg) in combination with vitamin $\mathrm{D}_{3}$ (5,000 IU) and standard anti-TB drug therapy activated CAMP gene expression and suppressed intracellular $M t b$ growth in MDMs $(94,97)$ (Table 1; Figure 1). Moreover, an in vitro study showed that vitamin $\mathrm{D}_{3}$ together with $\mathrm{PBA}$ treatment promoted autophagy and differentiation of DCs into a stretched CD14+/CD1a-DC subset and enhanced the production of reactive oxygen species and cathelicidin (48). Interestingly, $1,25(\mathrm{OH})_{2} \mathrm{D}_{3}$ upregulates the expression of autophagy-related proteins (ATGs), such as ATG5 and Beclin-1 and augments autophagosome initiation, and its fusion with the lysosome and restricts $M t b$ growth (Table 1; Figure 1) (40, $38,98)$. In vitro studies demonstrated that treatment of $M t b-$ infected macrophages with vitamin $\mathrm{D}_{3}$ plus $\mathrm{PBA}$ promotes colocalization of LL-37 and LC3-II proteins in autophagosomes $(49,50)$. A recent clinical study showed that cotreatment with PBA and vitamin $\mathrm{D}_{3}$ as an adjunct to standard chemotherapy reduces $M t b$ growth in MDMs and accelerates clinical recovery compared to the placebo group (97) (Table 2). These studies unveil a potential role of vitamin $\mathrm{D}_{3}$ in combination with PBA supplementation in the treatment of TB. However, more clinical studies are necessary to validate the potential of $\mathrm{D}_{3}$ and PBA as HDT against drug-resistant TB.
$1,25(\mathrm{OH})_{2} \mathrm{D}_{3}$ also acts as an anti-inflammatory agent by downregulating the production of proinflammatory cytokines and chemokines, such as IL- 6 and IL-12, TNF- $\alpha$, IL-17, IL-23, MIG, IP-10, MCP-1, by suppressing the NF- $\kappa B$ signaling pathway and augmenting the production of anti-inflammatory cytokines TGF- $\beta 1$, IL-4, and IL-10 in pulmonary TB $(41,43$, 109-112) (Table 1; Figure 1). Moreover, in vitro studies have shown that $1,25(\mathrm{OH})_{2} \mathrm{D}_{3}$ suppresses both $\mathrm{T}_{\mathrm{H}} 1$ and cytotoxic $\mathrm{T}$ cell response, whereas it enhances the differentiation of CD4+ CD25-Foxp3+ regulatory T cells, leading to significant reduction of IFN- $\gamma$ and IL-17 production in many clinical conditions including TB (44-47, 113-116) (Table 1). Two in vivo study conducted in TB patients showed that administration of a high dose of vitamin D (2.5 mg or 600,000 IU) with standard anti-TB drugs improved clinically as well as radiological readouts, suppressed antigen-stimulated proinflammatory cytokine production, and accelerated the resolution of inflammatory responses during treatment $(42,99)$ (Table 2). However, a recent study reported that vitamin $\mathrm{D}$ supplementation at $1.25 \mathrm{mg}$ (50,000 IU) with standard first-line anti-TB drugs corrected the vitamin D deficiency, without significantly altering the $M t b$ culture conversion rates in pulmonary TB patients $(92,93,100)$ (Table 2). Moreover, a cross sectional analysis reported that vitamin $\mathrm{D}$ supplementation enhanced sputum conversion only in TB patients with vitamin D receptor " $t t$ " genotype (93). This study suggests that polymorphisms in genes that are associated with vitamin $\mathrm{D}$ signaling pathways can influence the outcome of host response to TB. These conflicting results may be due to the variation in dose, duration of treatment, stage of disease and/or other factors. In addition, since the imbalance in vitamin D level increases the risk of TB (117), interindividual variation of basal vitamin D level among the TB patients may affect the study result. Hence, further studies of sufficient sample size with proper clinical settings are necessary to understand the beneficial effects of vitamin D supplementation in TB.

\section{HDT TARGETING AUTOPHAGY}

Autophagy is a lysosomal self-digestion process essential for cellular homeostasis, which can function as an innate defense mechanism during $M t b$ infection (118). In particular, it has been demonstrated that a phagosome containing the bacteria can fuse with an autophagosome and subsequently with the lysosome, resulting in pathogen killing (119). Virulent $M t b$ strains can modulate phagosome membrane by expressing the early-secreted antigen 6 secretion system (120). However, STING (stimulator of the interferon gene), a host protein capable of recognizing extracellular bacterial DNA, promotes delivery of bacteria to autophagosome, facilitating bacterial clearance (120). Autophagy can be induced via the inhibition of mammalian target of rapamycin complex 1 . Rapamycin is an immunosuppressive drug that inhibits mTOR and induces autophagy $(51,121)$ (Table 1; Figure 1). However, its application as HDT for TB is limited since rapamycin is metabolized by CYP3A4, a hepatic enzyme that is also induced by RIF, an anti-TB drug. Autophagy can also be induced by inhibiting 
TABLE 2 | HDT agents in the clinical trials for TB treatment.

\begin{tabular}{|c|c|c|c|c|c|}
\hline HDT agent & Hypothesis & $\begin{array}{l}\text { No. of } \\
\text { subjects }\end{array}$ & Dose & $\begin{array}{l}\text { Hypothesis } \\
\text { acceptance }\end{array}$ & Reference \\
\hline $\begin{array}{l}\text { PBA + vitamin } \\
\text { D3 }\end{array}$ & PBA + vitD3 enhance recovery in PTB patients. & 288 & $\begin{array}{l}500 \mathrm{mg}(\mathrm{PBA})+5,000 \mathrm{IU}(\mathrm{VitD} 3) \text { daily } \\
\text { for } 2 \text { months }\end{array}$ & Yes & Mily et al. (97) \\
\hline \multirow[t]{2}{*}{ Vitamin D3 } & $\begin{array}{l}\text { i. VitD3 supplementation could augment } \\
\text { faster recovery. }\end{array}$ & 259 & 600,000 IU two doses & Yes & $\begin{array}{l}\text { Salahuddin } \\
\text { et al. (99) }\end{array}$ \\
\hline & $\begin{array}{l}\text { ii. VitD3 supplementation improves treatment } \\
\text { response in PTB. }\end{array}$ & 199 & 50,000 IUs thrice weekly for 8 week & No & $\begin{array}{l}\text { Tukvadze } \\
\text { et al. (100) }\end{array}$ \\
\hline \multirow[t]{3}{*}{$\begin{array}{l}\text { Prednisolone/ } \\
\text { prednisone (PN) }\end{array}$} & $\begin{array}{l}\text { i. Adjunctive prednisolone treatment appraise } \\
\text { anti-TB treatment in HIV negative advanced PTB patients. }\end{array}$ & 178 & 20 mg twice times a day & Yes & $\begin{array}{l}\text { Bilaceroglu } \\
\text { et al. (59) }\end{array}$ \\
\hline & $\begin{array}{l}\text { ii. Prednisolone therapy enhances immune response } \\
\text { HIV-infected TB patients. }\end{array}$ & 187 & $2.75 \mathrm{mg} / \mathrm{kg}$ for 4 weeks & No & $\begin{array}{l}\text { Mayanja-Kizza } \\
\text { et al. (101) }\end{array}$ \\
\hline & $\begin{array}{l}\text { iii. Adjunctive PN treatment enhances sputum culture } \\
\text { conversion (meta-analysis). }\end{array}$ & 1806 & 134 mg/day & Yes & Wallis (102) \\
\hline Dexamethasone & $\begin{array}{l}\text { i. Adjunctive dexamethasone treatment can reduce } \\
\text { the risk of disability or death in TBM. }\end{array}$ & 545 & $\begin{array}{l}\text { Patients were graded and different } \\
\text { doses were administered }\end{array}$ & No & $\begin{array}{l}\text { Thwaites } \\
\text { et al. (103) }\end{array}$ \\
\hline \multirow[t]{2}{*}{$\mathrm{IFN}-\gamma$} & \multirow[t]{2}{*}{$\begin{array}{l}\text { i. IFN- } \gamma \text { treatment accelerates sputum smear conversion. } \\
\text { ii. Adjuvant IFN- } \gamma \text { inhalation augments recovery in MDR-TB. }\end{array}$} & 5 & $\begin{array}{l}500 \mu \mathrm{g} \text { three times a week } \\
\text { for } 1 \text { month }\end{array}$ & Yes & $\begin{array}{l}\text { Condos } \\
\text { et al. (104) }\end{array}$ \\
\hline & & 6 & $\begin{array}{l}\text { Two million IU three times a } \\
\text { week for } 6 \text { months }\end{array}$ & No & Koh et al. (105) \\
\hline $\mathrm{rIFN}-\gamma$ & $\begin{array}{l}\text { Adjunct rIFN- } \gamma \text { may reduce pulmonary inflammation } \\
\text { and promote earlier sputum clearance. }\end{array}$ & 89 & $200 \mu \mathrm{g}$ three times for 16 weeks & Yes & $\begin{array}{l}\text { Dawson } \\
\text { et al. (75) }\end{array}$ \\
\hline IFN- $\alpha$ & $\begin{array}{l}\text { Adjunct IFN- } \alpha \text { treatment improves treatment } \\
\text { response in MDR-TB }\end{array}$ & 7 & $\begin{array}{l}\text { Three million IU, three times a week for } \\
2 \text { months }\end{array}$ & No & $\begin{array}{l}\text { Giosuè } \\
\text { et al. (106) }\end{array}$ \\
\hline \multirow[t]{2}{*}{ rlL-2 } & $\begin{array}{l}\text { i. rlL-2 treatment enhances both the immune response } \\
\text { and bacterial clearance. }\end{array}$ & 110 & 225,000 IU twice daily for 30 days & No & $\begin{array}{l}\text { Johnson } \\
\text { et al. (107) }\end{array}$ \\
\hline & $\begin{array}{l}\text { ii. Adjunct IL-2 supplementation enhance treatment } \\
\text { response in MDR-TB. }\end{array}$ & 50 & $\begin{array}{l}500,000 \mathrm{IU} \text { once every other day at the } \\
\text { first, third, fifth, and seventh months }\end{array}$ & Yes & $\begin{array}{l}\text { Shen } \\
\text { et al. (108) }\end{array}$ \\
\hline Etanercept & $\begin{array}{l}\text { TNF blockade suppress inflammatory response and enhance } \\
\text { treatment response in HIV-associated TB }\end{array}$ & 16 & $\begin{array}{l}25 \text { mg, eight doses, twice weekly } \\
\text { beginning on day } 4 \text { of anti-TB therapy }\end{array}$ & Yes & $\begin{array}{l}\text { Wallis } \\
\text { et al. (81) }\end{array}$ \\
\hline $\begin{array}{l}\text { Mesenchymal } \\
\text { stromal cell }\end{array}$ & $\begin{array}{l}\text { Adjunct autologous treatment with bone marrow-derived } \\
\text { MSCs might improve clinical outcome in MDR/XDR-TB }\end{array}$ & 30 & Single-dose of $1 \times 10^{6} \mathrm{MSC}$ s per $\mathrm{kg}$ & Yes & $\begin{array}{l}\text { Skrahin } \\
\text { et al. (72) }\end{array}$ \\
\hline
\end{tabular}

PBA, phenylbutyrate; PTB, pulmonary tuberculosis; HIV, human immunodeficiency virus; IFN, interferon; rIFN- $\gamma$, recombinant IFN- $\gamma$; MDR, multidrug-resistant; XDR, extensively drug resistant.

epidermal growth factor receptor (EGFR)-mediated p38 MAPK signaling pathways. Indeed, gefitinib is an inhibitor of EGFR that activates autophagy, and administration of gefitinib $(100 \mathrm{mg} / \mathrm{kg})$ in absence of chemotherapy was shown to decrease intracellular $M t b$ growth in macrophages and in a mouse model (52) (Table 1). Thus, activation of autophagy via inhibition of EGFR may be a promising HDT avenue.

Anticonvulsant drugs such as carbamazepine have been shown to stimulate autophagy through inositol triphosphate $\left(\mathrm{IP}_{3}\right)$ depletion and AMP-activated protein kinase activation and kill intracellular $M t b$ in macrophages (53). Moreover, carbamazepine treatment without anti-TB drugs significantly reduced the MDR-TB burden in the lungs and spleen and diminished the inflammatory pulmonary infiltrate in mice (53) (Table 1). These studies suggest that HDT drugs that trigger autophagy induction and promote the intracellular killing of mycobacteria may play a significant role in the management of MDR-TB. In addition, following autophagy, the bacterial degradation products were shown to be loaded on the MHC class II molecule, helping to generate efficient adaptive immunity by stimulating the $\mathrm{T}$ cell response against $M t b$ (122).

\section{HDT TARGETING THE INFLAMMATORY RESPONSE}

The balance between pro- and anti-inflammatory responses is a critical factor in determining the fate of initial $M t b$ infection. Indeed, a shift toward either aggressive proinflammatory or aggressive anti-inflammatory cytokine response may lead to poor bacterial control and development of active disease $(11,123)$. Host inflammatory balance is influenced by the level of lipoxin A4 (LPX4) and leukotriene B4 (LTB4): increased production of LPX4 helps to maintain inflammatory balance and play a pivotal role in the control of TB progression (54), while LTB4 causes hyperinflammation and increases disease severity (24). The treatment with aspirin (acetylsalicylic acid), an antiinflammatory drug, enhances LXA4 production, which in turn suppresses neutrophil migration and TNF- $\alpha$ production, thereby regulating inflammatory pathology during mycobacterial infection, as has been suggested for tuberculous meningitis (TBM) $(24,55)$ (Table 1).

Prostaglandin and thromboxane are vasoconstrictors that facilitate platelet aggregation and regulate inflammation. 
Ibuprofen, an immunomodulatory drug that inhibits cyclooxygenase-1 (COX1) and COX2 and suppresses prostaglandin $\mathrm{H} 2$ and thromboxane production (124). Ibuprofen treatment without standard anti-TB drugs has been shown to reduce $M t b$ load and diminish inflammatory lung pathology in a murine model of active TB (56) (Table 1; Figure 1). Furthermore, an in vitro study reported that indomethacin, a non-steroidal anti-inflammatory drug that inhibits $\mathrm{COX} 1 / 2$ and regulates uncontrolled proliferation of $\mathrm{CD} 4+, \mathrm{CD} 8+$, and regulatory $\mathrm{T}$ cells contributing to TB pathogenesis (125) (Table 1). This suggests a potential role for indomethacin in alleviating the inflammatory response during active TB; however, the efficacy of these drugs, as adjunct to antibiotics, has yet to be validated under in vivo conditions.

The inflammatory response can also be regulated by downmodulating the activity of lipoxygenase (126). Zileuton is an inhibitor of the 5-lipoxygenase pathway, which suppresses the production of leukotrienes and downregulates inflammation, thus improving airway function in asthmatics (127). Zileuton treatment with or without anti-TB drugs modulates IL-1 $\beta$ mediated signaling pathways, controls exacerbated inflammation by regulating type 1 IFN production, augments prostaglandin E2 level, and significantly reduces $M t b$ burden and lung pathology in a mice model of pulmonary TB (57) (Table 1; Figure 1). However, this compound has not been validated in other, more relevantto-human models of TB.

Targeting immune response pathways downstream of the glucocorticoid receptor (GR) is another HDT strategy to control aggressive inflammation. Administration of corticosteroids, such as prednisone and dexamethasone (GR agonists), has been shown to ameliorate the proinflammatory response during $M t b$ infection by significantly downregulating the expression of IL-6, IL-8, MCP-1, and TNF- $\alpha(58,128)$ (Table 1; Figure 1). Corticosteroids that bind to GR have been tested as an adjunct to standard antibiotic therapy in various forms of TB such as pleural effusion, TBM and pericarditis and TB-IRIS in HIV coinfected patients (129). Although earlier studies with adjunct corticosteroid treatment found some beneficial effects such as improvement in lung radiography and pulmonary function at the initial stage of disease, these studies did not find any significant difference between anti-TB drugs with and without the HDT drug in long term studies (130). A recent meta-regression analysis by Wallis reported that corticosteroid with standard TB chemotherapy reduces the proportion of positive sputum culture from 15 to 2\% (102) (Table 2). It has been shown that corticosteroid plus anti-TB treatment reduces the mortality rate among TBM cases $(103,131)$ but did not prevent the severe disability associated with this disease (103) (Table 2). The corticosteroid supplementation as adjunct to antibiotics have also been reported to be beneficial in patients with tuberculous pericarditis (132); however, more studies are required to reach a solid conclusion. In addition, supplementation with corticosteroid alone was shown to have no significant improvement, compared to treatment with antibiotics alone, in PTB patients (133). Similarly, prednisolone therapy $(2.75 \mathrm{mg} / \mathrm{kg}$ for 4 weeks) in $187 \mathrm{HIV}-\mathrm{TB}$ coinfected patients did not show significant beneficial effect other than mild improvement in CD4+ T cell counts (101) (Table 2). In contrast, when prednisone was used as adjunct therapy in combination with standard anti-TB drugs, enhanced radiographic regression, and decreased bacillary load in advanced PTB patients $(59,134)$ (Table 2). However, detailed studies are required to corroborate the role of prednisone as an adjunct in the treatment of TB.

Inflammation can also be controlled by regulating the activity of phosphodiesterases (PDEs), a group of enzymes that hydrolyze cyclic adenosine and guanosine monophosphates to AMP (135). Using PDE4 inhibitors, such as CC-3052 (25 mg/kg body weight) and CC-11050 (25 or $50 \mathrm{mg} / \mathrm{kg}$ body weight), as adjunct to isoniazid, we have shown significantly reduced macrophage activation, expression of TNF- $\alpha$, lung fibrosis and necrosis, and tissue bacterial load in a mouse and rabbit models of pulmonary $\mathrm{TB}(31,60,136,137)$. Similarly, administration of a PDE3 inhibitor (cilostazol) $(10 \mathrm{mg} / \mathrm{kg}$ body weight) and a PDE5 inhibitor (sildenafil) (10 mg/kg body weight) together with standard TB treatment accelerates bacterial clearance from the lungs and reduces treatment duration by 1 month in a mouse model $(61,138)$ (Table 1; Figure 1). Thus, adjunct PDE inhibitors with anti-TB chemotherapy may help shorten treatment duration and improve treatment outcome.

During the active stage of infection, $M t b$ induces the expression of various matrix metalloproteinases (MMPs), such as MMP-1, MMP-3, MMP-7, MMP-9, and MMP-10, from lung epithelial cells and macrophages (139). MMPs degrade the pulmonary extracellular matrix, exacerbate the inflammation, and contribute to tissue damage and pulmonary cavitation in TB patients $(140,141)$. Hence, the inhibition of MMP activity is a promising HDT strategy to alleviate inflammatory pathology in patients. Doxycycline, a tetracycline antibiotic, was shown to suppress the expression of MMP-1, MMP-3, MMP-9, and TNF- $\alpha$ in $M t b$-infected macrophages and epithelial cells by inhibiting MMP promoter activation (136) (Table 1; Figure 1). Moreover, doxycycline treatment significantly reduced the lung bacterial burden in guinea pigs in a dose-dependent manner (62). However, this study did not investigate the effect of adjunctive doxycycline treatment with standard anti-TB chemotherapy. Another study reported that administration of SB-3CT; an inhibitor of MMPs, along with conventional anti-TBM drugs significantly suppressed the expression of MMP-9 and enhanced $M t b$ clearance in a mouse model of TBM (63).

\section{HDT TARGETING CELL-MEDIATED IMMUNITY}

Cell-mediated immunity is the central part of the adaptive immune response during $M t b$ infection (142), and modulation of the cell-mediated immune response is a promising HDT approach for TB treatment. Several molecules have been identified for their ability to modulate the cell-mediated immune response. Statin is a well-known inhibitor of 3-hydroxy3-methylglutaryl-CoA that reduces serum LDL cholesterol level in humans (143). In addition, statin acts as a potent anti-inflammatory agent, regulating inflammation and reducing tissue damage in patients with sepsis and pneumonia (144, 145). It activates transcription factor Kruppel-like factor (KLF) 
and downregulates expression of TNF- $\alpha$, IL- $1 \beta$, IL- 6 , and IL-8 from lymphocytes (64). Statin also decreases IFN- $\gamma$ production, downregulates the expression of MHC class II molecules, and impairs the CD4 T cell activation (146). A murine model TB study revealed that statin treatment significantly reduces lung bacterial load and disease pathology and this effect was mainly due to a decrease in the membrane cholesterol levels, which promotes phagosomal maturation/acidification and autophagy (65) (Table 1; Figure 1). Moreover, administration of simvastatin augments the anti-TB activities of first-line drugs INH, RIF and PZA in a mouse model (66). Moreover, epidemiological studies have reported a reduced frequency of active $T B$ incidence in statin users compared to non-statin users $(147,148)$, suggesting that statin therapy lowers the risk of active TB development.

The poly(ADP-ribose) polymerase (PARP) inhibitor; niraparib enhances mitochondrial fatty acid oxidation and helps to alleviate oxidative stress in immune cells (67). Since mitochondrial fatty acid oxidation helps to maintain memory CD8 T cell responses (149), PARP inhibitors may promote the cell-mediated immune response during $M t b$ infection (Table 1; Figure 1). However, more studies are required to validate the role this drug in TB treatment. The nutraceutical resveratrol (trans-3,5,4' -trihydroxystilbene) promotes mitochondrial biogenesis and reduces oxidative stress by increasing the cellular respiratory capacity (68). In addition, resveratrol also regulates severe inflammation by increasing regulatory $\mathrm{T}$ cell frequency and apoptosis of activated CD8 T cells $(69,150)$, which may help to control the aggressive inflammatory response and tissue damage during the active stage of TB (Table 1). Inhibitory receptors, such as programmed cell death 1 (PD-1), promote apoptosis of activated $\mathrm{T}$ cells, whereas its regulation is critical for differentiation as well as the proliferation of regulatory $\mathrm{T}$ cells. Immune checkpoint inhibitors, including nivolumab/ pembrolizumab, inhibit the expression of PD-1 on CD8+ $\mathrm{T}$ cells and augment cell-mediated immune responses $(70,71)$. Similarly, cytotoxic T-lymphocyte-associated protein 4 (CTLA4), expressed by activated T cells, binds to CD80 and CD86 on antigen-presenting cells and transmits inhibitory signal (151). Ipilimumab, a CTLA-4 inhibitor, regulates the immune suppression mediated by CTLA-4 and promotes CD8+ T cellmediated immune function (152) (Table 1; Figure 1). Further, in vivo studies are needed to understand the therapeutic effect of these drugs. The cell-mediated immune response is also enhanced by blocking the activity of lymphocyte activation gene 3 (LAG3), a receptor expressed mainly by regulatory $\mathrm{T}$ cells. LAG3 interacts with class II MHC molecules and downregulates CD4+ antigen-specific immune response, their proliferation, activation and homeostasis (153). Another study reported that LAG3 expression more specific to $M t b$ infection and this is coincides with bacterial burden and disease progression (154). This suggests that inhibition of LAG3 function using antiLAG3 antibody upregulates $\mathrm{T}$ cell-mediated immune response and reduces bacterial burden in the lungs (Table 1; Figure 1). In sum, there are several approaches that can be exploited as an adjunct therapy to augment cell-mediated adaptive immune response during $M t b$ infection.

\section{IMMUNE CELL THERAPY AS HDT FOR TB}

Direct transfer of immune cells, such as antigen-specific $\mathrm{T}$ cells, is an emerging HDT strategy for the management of cancer and infectious diseases $(155,156)$. Similarly, direct administration of mesenchymal stromal cells (MSCs) and antigen-specific $\mathrm{T}$ cells has been evaluated for TB treatment (157) (Table 1). MSCs are tissue resident, multipotent stromal cells that facilitate organ homeostasis and tissue repair following infection and/or inflammation. Treatment of MDR and XDR TB patients with a single dose autologous bone marrow derived MSCs as an adjunct with standard drug regimens enhances T cells and DC immune response specific to $M t b$ antigen $(72,73)$ (Table 2$)$. In addition, fine-tuning of the $\mathrm{T}$ cell-mediated immune response to $M t b$ is a new and emerging concept in HDT (158). For instance, it has been shown that the CD8+ T cell response can be shaped by specific Mtb epitopes (74) (Table 1). Thus, the adoptive transfer of activated T cells, such as CD8+ cells, has the potential to be a new promising strategy in the treatment of MDR and/or XDR-TB cases.

\section{CYTOKINE SUPPLEMENTATION AS HDT FOR TB}

Interferon- $\gamma$ is an important cytokine that activates innate immune functions and mediates antigen-specific $\mathrm{T}$ cell immunity in response to $M t b$ infection $(142,159)$. Earlier studies reported that inhalation of aerosolized IFN- $\gamma$ in MDR-TB patients ( $500 \mu \mathrm{g}$, three times a week for $1 \mathrm{month})$ is associated with sputum smear conversion and radiological improvements $(104,160)$. However, another study reported that IFN- $\gamma$ treatment at two million IU, administered three times a week for 6 months, in six MDR-TB patients had no effect on culture conversion rate in long term treatment (105) (Table 2). A randomized controlled clinical study has shown that aerosolized recombinant IFN- $\gamma$ as an adjunct to standard anti-TB therapy suppressed the production of proinflammatory cytokines, such as IL-1 $\beta$, IL-6, and IL-8 (75). Furthermore, recombinant IFN- $\gamma$ supplementation therapy either by nebulization or by subcutaneous injection $(200 \mu \mathrm{g}$ three times per week over 4 months) elevated the CD4+ lymphocytes' response to purified protein derivative and enhanced $M t b$ clearance in sputum, thus improving the response to treatment in cavitary-TB patients (75) (Tables 1 and 2). While these results are promising, further studies are required to validate the beneficial effect of IFN- $\gamma$ supplementation as adjuvant therapy in patients with poor responsiveness to anti-TB therapy and in MDR-TB patients. Similarly, a study investigating whether adjunct IFN- $\alpha$ supplementation can improve the anti-TB treatment response among MDR-TB patients did not find significant clinical improvement (106) (Table 2). IL-2 is another important cytokine that is required for the proliferation of antigen-specific CD4+ and CD8+ T cells during $M t b$ infection (161). A randomized controlled clinical trial to test the efficacy of adjunctive IL-2 supplementation with standard anti-TB therapy did not show significant clinical benefits, compared to treatment with antibiotics without IL-2 
(107). Interestingly, in a recent clinical study carried out with 50 MDR-TB patients, adjunct supplementation of recombinant human IL-2 (500,000 IU in alternative days and months up to 7 months) in improved immunity status and sputum smear conversion (108) (Table 2). These observations not only highlight the complex roles of cytokines in regulating immune cell functions but also the potential of modulating cytokine activities as HDT for TB treatment.

\section{ANTI-Mtb ANTIBODIES AS HDT FOR TB}

The role of B cell-mediated humoral immunity in shaping the host response to $M t b$ has been an active area of research for the past several years (162). Recent studies have shown that B cells regulate neutrophil infiltration by modulating IL- 17 response and control inflammation during $M t b$ infection in mouse lungs (163). Furthermore, FcR-mediated phagocytosis of $M t b$ was shown to enhance phagolysosomal fusion and mycopeptide presentation to $\mathrm{T}$ cells, thus augmenting the Th1 response $(164,165)$. In addition, other studies reported that precoating of bacilli with serum rich in anti-LAM antibodies enhances phagolysosomal fusion and increases the abundance of IFN- $\gamma$-expressing CD4+ and CD8+ T cells $(166,167)$ (Table 1; Figure 1). It has also been reported that high levels of anti-Mtb IgG3 antibodies prevent reactivation of TB in high-risk individuals (76). Another study showed a significantly decreased bacterial load in the lungs of $M t b$-infected mice following intranasal administration of human gamma globulin (168). Similarly, passive administration of a combination of human monoclonal IgAs against $M t b$ antigens in combination with IFN- $\gamma$ has been shown to protect against subsequent $M t b$ infection in a mouse model (77). Together, these results highlight the potential of $M t b$ antigen-specific antibodies as adjunctive vaccine candidates and indicate that passive transfer of these antibodies with/without anti-TB therapy can be a novel HDT against $M t b$ infection (169). However, further detailed studies are required to validate these approaches.

\section{SUMMARY AND CONCLUSION}

Investigators are actively searching for new treatment strategies for better management of TB and to prevent the emergence of MDR and XDR TB. Targeting and manipulating host factors impacted by $M t b$ can be used for HDT to control infection and dissemination within/outside the lung. HDT is an emerging strategy, where the bacterial infection is controlled primarily by restoring the impaired host immune responses. Small molecules and biological agents that enhance macrophage antimicrobial activities, induce autophagy, and alleviate excessive

\section{REFERENCES}

1. World Health Organization (WHO). Global Tuberculosis Report. Geneva: World Health Organization (WHO) (2016).

2. World Health Organization (WHO). Tuberculosis Fact Sheet. Geneva: World Health Organization (WHO) (2017).

3. Azad AK, Sadee W, Schlesinger LS. Innate immune gene polymorphisms in tuberculosis. Infect Immun (2012) 80(10):3343-59. doi:10.1128/IAI.00443-12 inflammation have been shown to be promising candidates for HDT targeting both drug-sensitive and -resistant TB. Since HDT drugs target host cell functions, infecting $M t b$ strains are not expected to develop resistance against these drugs. In addition, HDT agents that have the potential to reduce lung matrix destruction can be beneficial in restoring lung function following the treatment of cavitary TB and Immune Reconstitution Inflammatory Syndrome associated with HIV infection. Multiple studies suggest that adjunctive HDT with standard chemotherapy has the potential to accelerate bacillary clearance and disease pathology, thus enhancing patient response to treatment, improving lung function, reducing drug toxicity, helping prevent the emergence of drug-resistant TB, and shortening treatment duration. While most of the HDT agents tested have shown promising results in in vitro studies and in animal models, clinical trials to evaluate the implication of these HDT agents have either failed to reproduce similar beneficial effects as model systems or revealed controversial findings. There are several factors that may contribute to the contrasting results among these studies, such as the number and nature of study subjects (under powered studies leads to misinterpretation) and their age, variation in dose selection, different life style of study subjects including food habitat, smoking, and alcohol consumption etc. In addition, progression of $M t b$ infection into active disease is influenced by several other factors such as coinfection, immune suppression, metabolic disorders, ethnicity, malnutrition, the genetic makeup of individuals that reflects in genetic polymorphisms associated with susceptibility/resistance to infection $(3,4)$. Therefore, future clinical studies with the implementation of carefully designed clinical trials with more meticulous inclusion and exclusion criteria are warranted to validate the efficiency of existing HDTs and to identify new HDT agents that can target multiple biological host functions. These HDTs, as adjunct to existing/new antibiotics, can potentially improve the quality of treatment for the millions of patients suffering from various forms of TB worldwide.

\section{AUTHOR CONTRIBUTIONS}

SS conceived the concept. AK and SS wrote/edited the manuscript and agreed for submission.

\section{FUNDING}

This study was supported by a grant from NIH/NIAID (AI110335) and by a grant from the Bill and Melinda Gates Foundation (OPP1157210) to SS.
4. Zumla A, Raviglione M, Hafner R, von Reyn CF. Tuberculosis. N Engl J Med (2013) 368(8):745-55. doi:10.1056/NEJMra1200894

5. Sotgiu G, Sulis G, Matteelli A. Tuberculosis - a World Health Organization Perspective. Microbiol Spectr (2017) 5(1):TNMI7-0036-2016. doi:10.1128/ microbiolspec.TNMI7-0036-2016

6. O'Garra A, Redford PS, McNab FW, Bloom CI, Wilkinson RJ, Berry MP. The immune response in tuberculosis. Annu Rev Immunol (2013) 31: 475-527. doi:10.1146/annurev-immunol-032712-095939 
7. Algood HM, Lin PL, Flynn JL. Tumor necrosis factor and chemokine interactions in the formation and maintenance of granulomas in tuberculosis. Clin Infect Dis (2005) 41(Suppl 3):S189-93. doi:10.1086/429994

8. Akira S, Uematsu S, Takeuchi O. Pathogen recognition and innate immunity. Cell (2006) 124(4):783-801. doi:10.1016/j.cell.2006.02.015

9. Lin PL, Myers A, Smith L, Bigbee C, Bigbee M, Fuhrman C, et al. Tumor necrosis factor neutralization results in disseminated disease in acute and latent Mycobacterium tuberculosis infection with normal granuloma structure in a cynomolgus macaque model. Arthritis Rheum (2010) 62(2):340-50. doi:10.1002/art.27271

10. Lazarevic V, Nolt D, Flynn JL. Long-term control of Mycobacterium tuberculosis infection is mediated by dynamic immune responses. JImmunol (2005) 175(2):1107-17. doi:10.4049/jimmunol.175.2.1107

11. Lin PL, Flynn JL. Understanding latent tuberculosis: a moving target. J Immunol (2010) 185(1):15-22. doi:10.4049/jimmunol.0903856

12. Orme IM, Basaraba RJ. The formation of the granuloma in tuberculosis infection. Semin Immunol (2014) 26(6):601-9. doi:10.1016/j.smim.2014. 09.009

13. Gutierrez MG, Master SS, Singh SB, Taylor GA, Colombo MI, Deretic V. Autophagy is a defense mechanism inhibiting BCG and Mycobacterium tuberculosis survival in infected macrophages. Cell (2004) 119(6):753-66. doi:10.1016/j.cell.2004.11.038

14. Aberdein JD, Cole J, Bewley MA, Marriott HM, Dockrell DH. Alveolar macrophages in pulmonary host defence the unrecognized role of apoptosis as a mechanism of intracellular bacterial killing. Clin Exp Immunol (2013) 174(2):193-202. doi:10.1111/cei.12170

15. Weiss G, Schaible UE. Macrophage defense mechanisms against intracellular bacteria. Immunol Rev (2015) 264(1):182-203. doi:10.1111/imr.12266

16. Deretic V, Singh S, Master S, Harris J, Roberts E, Kyei G, et al. Mycobacterium tuberculosis inhibition of phagolysosome biogenesis and autophagy as a host defence mechanism. Cell Microbiol (2006) 8(5):719-27. doi:10.1111/j.1462-5822.2006.00705.x

17. Shin DM, Jeon BY, Lee HM, Jin HS, Yuk JM, Song CH, et al. Mycobacterium tuberculosis eis regulates autophagy, inflammation, and cell death through redox-dependent signaling. PLoS Pathog (2010) 6(12):e1001230. doi:10.1371/journal.ppat.1001230

18. Ernst JD. The immunological life cycle of tuberculosis. Nat Rev Immunol (2012) 12(8):581-91. doi:10.1038/nri3259

19. Oddo M, Renno T, Attinger A, Bakker T, MacDonald HR, Meylan PR. Fas ligand-induced apoptosis of infected human macrophages reduces the viability of intracellular Mycobacterium tuberculosis. J Immunol (1998) 160(11):5448-54.

20. Singh SB, Davis AS, Taylor GA, Deretic V. Human IRGM induces autophagy to eliminate intracellular mycobacteria. Science (2006) 313(5792): 1438-41. doi:10.1126/science.1129577

21. Russell MS, Dudani R, Krishnan L, Sad S. IFN-gamma expressed by $\mathrm{T}$ cells regulates the persistence of antigen presentation by limiting the survival of dendritic cells. J Immunol (2009) 183(12):7710-8. doi:10.4049/ jimmunol.0901274

22. Lin $Y$, Ritchea $S$, Logar A, Slight S, Messmer M, Rangel-Moreno J, et al. Interleukin-17 is required for $\mathrm{T}$ helper 1 cell immunity and host resistance to the intracellular pathogen Francisella tularensis. Immunity (2009) 31(5):799-810. doi:10.1016/j.immuni.2009.08.025

23. Stegelmann F, Bastian M, Swoboda K, Bhat R, Kiessler V, Krensky AM, et al. Coordinate expression of CC chemokine ligand 5, granulysin, and perforin in $\mathrm{CD} 8+\mathrm{T}$ cells provides a host defense mechanism against Mycobacterium tuberculosis.J Immunol (2005) 175(11):7474-83. doi:10.4049/ jimmunol.175.11.7474

24. Tobin DM, Roca FJ, Oh SF, McFarland R, Vickery TW, Ray JP, et al. Host genotype-specific therapies can optimize the inflammatory response to mycobacterial infections. Cell (2012) 148(3):434-46. doi:10.1016/j. cell.2011.12.023

25. Roca FJ, Ramakrishnan L. TNF dually mediates resistance and susceptibility to mycobacteria via mitochondrial reactive oxygen species. Cell (2013) 153(3):521-34. doi:10.1016/j.cell.2013.03.022

26. Ravimohan S, Tamuhla N, Steenhoff AP, Letlhogile R, Nfanyana K, Bellamy SL, et al. Immunological profiling of tuberculosis-associated immune reconstitution inflammatory syndrome and non-immune reconstitution inflammatory syndrome death in HIV-infected adults with pulmonary tuberculosis starting antiretroviral therapy: a prospective observational cohort study. Lancet Infect Dis (2015) 15(4):429-38. doi:10.1016/S1473-3099(15)70008-3

27. Zumla A, Rao M, Parida SK, Keshavjee S, Cassell G, Wallis R, et al. Inflammation and tuberculosis: host-directed therapies. J Intern Med (2015) 277(4):373-87. doi:10.1111/joim.12256

28. Wallis RS, Hafner R. Advancing host-directed therapy for tuberculosis. Nat Rev Immunol (2015) 15(4):255-63. doi:10.1038/nri3813

29. Zumla A, Rao M, Dodoo E, Maeurer M. Potential of immunomodulatory agents as adjunct host-directed therapies for multidrug-resistant tuberculosis. BMC Med (2016) 14:89. doi:10.1186/s12916-016-0635-1

30. Keane J, Gershon S, Wise RP, Mirabile-Levens E, Kasznica J, Schwieterman WD, et al. Tuberculosis associated with infliximab, a tumor necrosis factor alpha-neutralizing agent. N Engl J Med (2001) 345(15):1098-104. doi:10.1056/NEJMoa011110

31. Koo MS, Manca C, Yang G, O’Brien P, Sung N, Tsenova L, et al. Phosphodiesterase 4 inhibition reduces innate immunity and improves isoniazid clearance of Mycobacterium tuberculosis in the lungs of infected mice. PLoS One (2011) 6(2):e17091. doi:10.1371/journal.pone. 0017091

32. Tsenova L, O'Brien P, Holloway J, Peixoto B, Soteropoulos P, Fallows D, et al. Etanercept exacerbates inflammation and pathology in a rabbit model of active pulmonary tuberculosis. J Interferon Cytokine Res (2014) 34(9): 716-26. doi:10.1089/jir.2013.0123

33. Bourigault ML, Vacher R, Rose S, Olleros ML, Janssens JP, Quesniaux VF, et al. Tumor necrosis factor neutralization combined with chemotherapy enhances Mycobacterium tuberculosis clearance and reduces lung pathology. Am J Clin Exp Immunol (2013) 2(1):124-34.

34. Oehlers SH, Cronan MR, Scott NR, Thomas MI, Okuda KS, Walton EM, et al. Interception of host angiogenic signalling limits mycobacterial growth. Nature (2015) 517(7536):612-5. doi:10.1038/nature13967

35. Datta M, Via LE, Kamoun WS, Liu C, Chen W, Seano G, et al. Anti-vascular endothelial growth factor treatment normalizes tuberculosis granuloma vasculature and improves small molecule delivery. Proc Natl Acad Sci U S A (2015) 112(6):1827-32. doi:10.1073/pnas.1424563112

36. Liu PT, Stenger S, Tang DH, Modlin RL. Cutting edge: vitamin D-mediated human antimicrobial activity against Mycobacterium tuberculosis is dependent on the induction of cathelicidin. JImmunol (2007) 179(4):2060-3. doi:10.4049/jimmunol.179.4.2060

37. Liu PT, Schenk M, Walker VP, Dempsey PW, Kanchanapoomi M, Wheelwright $\mathrm{M}$, et al. Convergence of IL-1beta and VDR activation pathways in human TLR2/1-induced antimicrobial responses. PLoS One (2009) 4(6):e5810. doi:10.1371/journal.pone.0005810

38. Yuk JM, Shin DM, Lee HM, Yang CS, Jin HS, Kim KK, et al. Vitamin D3 induces autophagy in human monocytes/macrophages via cathelicidin. Cell Host Microbe (2009) 6(3):231-43. doi:10.1016/j.chom.2009.08.004

39. Verway M, Bouttier M, Wang TT, Carrier M, Calderon M, An BS, et al. Vitamin D induces interleukin-1beta expression: paracrine macrophage epithelial signaling controls M. tuberculosis infection. PLoS Pathog (2013) 9(6):e1003407. doi:10.1371/journal.ppat.1003407

40. Campbell GR, Spector SA. Vitamin D inhibits human immunodeficiency virus type 1 and Mycobacterium tuberculosis infection in macrophages through the induction of autophagy. PLoS Pathog (2012) 8(5):e1002689. doi:10.1371/journal.ppat.1002689

41. Coussens A, Timms PM, Boucher BJ, Venton TR, Ashcroft AT, Skolimowska $\mathrm{KH}$, et al. 1alpha,25-dihydroxyvitamin D3 inhibits matrix metalloproteinases induced by Mycobacterium tuberculosis infection. Immunology (2009) 127(4):539-48. doi:10.1111/j.1365-2567.2008.03024.x

42. Coussens AK, Wilkinson RJ, Hanifa Y, Nikolayevskyy V, Elkington PT, Islam K, et al. Vitamin D accelerates resolution of inflammatory responses during tuberculosis treatment. Proc Natl Acad Sci U S A (2012) 109(38):15449-54. doi:10.1073/pnas.1200072109

43. Song Y, Hong J, Liu D, Lin Q, Lai G. 1,25-dihydroxyvitamin D3 inhibits nuclear factor kappa B activation by stabilizing inhibitor IkappaBalpha via mRNA stability and reduced phosphorylation in passively sensitized human airway smooth muscle cells. Scand J Immunol (2013) 77(2):109-16. doi:10.1111/sji.12006

44. Imazeki I, Matsuzaki J, Tsuji K, Nishimura T. Immunomodulating effect of vitamin D3 derivatives on type-1 cellular immunity. Biomed Res (2006) 27(1):1-9. doi:10.2220/biomedres.27.1 
45. Jeffery LE, Burke F, Mura M, Zheng Y, Qureshi OS, Hewison M, et al. 1,25-dihydroxyvitamin D3 and IL-2 combine to inhibit T cell production of inflammatory cytokines and promote development of regulatory T cells expressing CTLA-4 and FoxP3. J Immunol (2009) 183(9):5458-67. doi:10.4049/jimmunol.0803217

46. Baeke F, Korf H, Overbergh L, Verstuyf A, Thorrez L, Van Lommel L, et al. The vitamin D analog, TX527, promotes a human CD4+CD25highCD127low regulatory $\mathrm{T}$ cell profile and induces a migratory signature specific for homing to sites of inflammation. J Immunol (2011) 186(1):132-42. doi:10.4049/jimmunol.1000695

47. Harishankar M, Anbalagan S, Selvaraj P. Effect of vitamin D3 on chemokine levels and regulatory T-cells in pulmonary tuberculosis. Int Immunopharmacol (2016) 34:86-91. doi:10.1016/j.intimp.2016.02.021

48. van der Does AM, Kenne E, Koppelaar E, Agerberth B, Lindbom L. Vitamin $\mathrm{D}(3)$ and phenylbutyrate promote development of a human dendritic cell subset displaying enhanced antimicrobial properties. JLeukoc Biol (2014) 95(6):883-91. doi:10.1189/jlb.1013549

49. Coussens AK, Wilkinson RJ, Martineau AR. Phenylbutyrate is bacteriostatic against Mycobacterium tuberculosis and regulates the macrophage response to infection, synergistically with 25-hydroxy-vitamin D3. PLoS Pathog (2015) 11(7):e1005007. doi:10.1371/journal.ppat.1005007

50. Rekha RS, Rao Muvva SS, Wan M, Raqib R, Bergman P, Brighenti S, et al. Phenylbutyrate induces LL-37-dependent autophagy and intracellular killing of Mycobacterium tuberculosis in human macrophages. Autophagy (2015) 11(9):1688-99. doi:10.1080/15548627.2015.1075110

51. Corcelle EA, Puustinen P, Jaattela M. Apoptosis and autophagy: targeting autophagy signalling in cancer cells -'trick or treats'? FEBS J (2009) 276(21):6084-96. doi:10.1111/j.1742-4658.2009.07332.x

52. Stanley SA, Barczak AK, Silvis MR, Luo SS, Sogi K, Vokes M, et al. Identification of host-targeted small molecules that restrict intracellular Mycobacterium tuberculosis growth. PLoS Pathog (2014) 10(2):e1003946. doi:10.1371/journal.ppat.1003946

53. Schiebler M, Brown K, Hegyi K, Newton SM, Renna M, Hepburn L, et al. Functional drug screening reveals anticonvulsants as enhancers of mTOR-independent autophagic killing of Mycobacterium tuberculosis through inositol depletion. EMBOMolMed(2015) 7(2):127-39. doi:10.15252/ emmm.201404137

54. Tobin DM, Ramakrishnan L. TB: the Yin and Yang of lipid mediators. Curr Opin Pharmacol (2013) 13(4):641-5. doi:10.1016/j.coph.2013.06.007

55. Morris T, Stables M, Hobbs A, de Souza P, Colville-Nash P, Warner T, et al. Effects of low-dose aspirin on acute inflammatory responses in humans. J Immunol (2009) 183(3):2089-96. doi:10.4049/jimmunol.0900477

56. Vilaplana C, Marzo E, Tapia G, Diaz J, Garcia V, Cardona PJ. Ibuprofen therapy resulted in significantly decreased tissue bacillary loads and increased survival in a new murine experimental model of active tuberculosis. J Infect Dis (2013) 208(2):199-202. doi:10.1093/infdis/jit152

57. Mayer-Barber KD, Andrade BB, Oland SD, Amaral EP, Barber DL, Gonzales J, et al. Host-directed therapy of tuberculosis based on interleukin-1 and type I interferon crosstalk. Nature (2014) 511(7507):99-103. doi:10.1038/nature13489

58. Blum CA, Nigro N, Briel M, Schuetz P, Ullmer E, Suter-Widmer I, et al. Adjunct prednisone therapy for patients with community-acquired pneumonia: a multicentre, double-blind, randomised, placebo-controlled trial. Lancet (2015) 385(9977):1511-8. doi:10.1016/S0140-6736(14)62447-8

59. Bilaceroglu S, Perim K, Buyuksirin M, Celikten E. Prednisolone: a beneficial and safe adjunct to antituberculosis treatment? A randomized controlled trial. Int J Tuberc Lung Dis (1999) 3(1):47-54.

60. Subbian S, Tsenova L, Holloway J, Peixoto B, O’Brien P, Dartois V, et al. Adjunctive phosphodiesterase- 4 inhibitor therapy improves antibiotic response to pulmonary tuberculosis in a rabbit model. EBioMedicine (2016) 4:104-14. doi:10.1016/j.ebiom.2016.01.015

61. Maiga M, Ammerman NC, Maiga MC, Tounkara A, Siddiqui S, Polis M, et al. Adjuvant host-directed therapy with types 3 and 5 but not type 4 phosphodiesterase inhibitors shortens the duration of tuberculosis treatment. J Infect Dis (2013) 208(3):512-9. doi:10.1093/infdis/jit187

62. Walker NF, Clark SO, Oni T, Andreu N, Tezera L, Singh S, et al. Doxycycline and HIV infection suppress tuberculosis-induced matrix metalloproteinases. Am J Respir Crit Care Med (2012) 185(9):989-97. doi:10.1164/ rccm.201110-17690C
63. Majeed S, Radotra BD, Sharma S. Adjunctive role of MMP-9 inhibition along with conventional anti-tubercular drugs against experimental tuberculous meningitis. Int J Exp Pathol (2016) 97(3):230-7. doi:10.1111/iep.12191

64. Jain MK, Ridker PM. Anti-inflammatory effects of statins: clinical evidence and basic mechanisms. Nat Rev Drug Discov (2005) 4(12):977-87. doi:10.1038/nrd1901

65. Parihar SP, Guler R, Khutlang R, Lang DM, Hurdayal R, Mhlanga MM, et al. Statin therapy reduces the Mycobacterium tuberculosis burden in human macrophages and in mice by enhancing autophagy and phagosome maturation. J Infect Dis (2014) 209(5):754-63. doi:10.1093/infdis/ jit550

66. Skerry C, Pinn ML, Bruiners N, Pine R, Gennaro ML, Karakousis PC. Simvastatin increases the in vivo activity of the first-line tuberculosis regimen. J Antimicrob Chemother (2014) 69(9):2453-7. doi:10.1093/jac/ dku166

67. Pirinen E, Canto C, Jo YS, Morato L, Zhang H, Menzies KJ, et al. Pharmacological inhibition of poly(ADP-ribose) polymerases improves fitness and mitochondrial function in skeletal muscle. Cell Metab (2014) 19(6):1034-41. doi:10.1016/j.cmet.2014.04.002

68. Beeson CC, Beeson GC, Schnellmann RG. A high-throughput respirometric assay for mitochondrial biogenesis and toxicity. Anal Biochem (2010) 404(1):75-81. doi:10.1016/j.ab.2010.04.040

69. Wang B, Sun J, Li X, Zhou Q, Bai J, Shi Y, et al. Resveratrol prevents suppression of regulatory T-cell production, oxidative stress, and inflammation of mice prone or resistant to high-fat diet-induced obesity. Nutr Res (2013) 33(11):971-81. doi:10.1016/j.nutres.2013.07.016

70. Gros A, Robbins PF, Yao X, Li YF, Turcotte S, Tran E, et al. PD-1 identifies the patient-specific CD8(+) tumor-reactive repertoire infiltrating human tumors. J Clin Invest (2014) 124(5):2246-59. doi:10.1172/JCI73639

71. Borch TH, Donia M, Andersen MH, Svane IM. Reorienting the immune system in the treatment of cancer by using anti-PD-1 and anti-PD-L1 antibodies. Drug Discov Today (2015) 20(9):1127-34. doi:10.1016/j.drudis.2015. 07.003

72. Skrahin A, Ahmed RK, Ferrara G, Rane L, Poiret T, Isaikina Y, et al. Autologous mesenchymal stromal cell infusion as adjunct treatment in patients with multidrug and extensively drug-resistant tuberculosis: an open-label phase 1 safety trial. Lancet Respir Med (2014) 2(2):108-22. doi:10.1016/S2213-2600(13)70234-0

73. Joshi L, Chelluri LK, Gaddam S. Mesenchymal stromal cell therapy in MDR/ XDR tuberculosis: a concise review. Arch Immunol Ther Exp (Warsz) (2015) 63(6):427-33. doi:10.1007/s00005-015-0347-9

74. Axelsson-Robertson R, Loxton AG, Walzl G, Ehlers MM, Kock MM, Zumla A, et al. A broad profile of co-dominant epitopes shapes the peripheral Mycobacterium tuberculosis specific CD8+ T-cell immune response in South African patients with active tuberculosis. PLoS One (2013) 8(3):e58309. doi:10.1371/journal.pone.0058309

75. Dawson R, Condos R, Tse D, Huie ML, Ress S, Tseng CH, et al. Immunomodulation with recombinant interferon-gammalb in pulmonary tuberculosis. PLoS One (2009) 4(9):e6984. doi:10.1371/journal.pone. 0006984

76. Encinales L, Zuniga J, Granados-Montiel J, Yunis M, Granados J, Almeciga I, et al. Humoral immunity in tuberculin skin test anergy and its role in high-risk persons exposed to active tuberculosis. Mol Immunol (2010) 47(5):1066-73. doi:10.1016/j.molimm.2009.11.005

77. Balu S, Reljic R, Lewis MJ, Pleass RJ, McIntosh R, van Kooten C, et al. A novel human IgA monoclonal antibody protects against tuberculosis. J Immunol (2011) 186(5):3113-9. doi:10.4049/jimmunol.1003189

78. Chakravarty SD, Zhu G, Tsai MC, Mohan VP, Marino S, Kirschner DE, et al. Tumor necrosis factor blockade in chronic murine tuberculosis enhances granulomatous inflammation and disorganizes granulomas in the lungs. Infect Immun (2008) 76(3):916-26. doi:10.1128/IAI.01011-07

79. Cosma CL, Sherman DR, Ramakrishnan L. The secret lives of the pathogenic mycobacteria. Annu Rev Microbiol (2003) 57:641-76. doi:10.1146/annurev. micro.57.030502.091033

80. Ehlers S, Schaible UE. The granuloma in tuberculosis: dynamics of a host-pathogen collusion. Front Immunol (2012) 3:411. doi:10.3389/fimmu. 2012.00411

81. Wallis RS, Kyambadde P, Johnson JL, Horter L, Kittle R, Pohle M, et al. A study of the safety, immunology, virology, and microbiology of adjunctive 
etanercept in HIV-1-associated tuberculosis. AIDS (2004) 18(2):257-64. doi:10.1097/00002030-200401230-00015

82. Kumar NP, Banurekha VV, Nair D, Babu S. Circulating angiogenic factors as biomarkers of disease severity and bacterial burden in pulmonary tuberculosis. PLoS One (2016) 11(1):e0146318. doi:10.1371/journal.pone.0146318

83. Kumar NP, Velayutham B, Nair D, Babu S. Angiopoietins as biomarkers of disease severity and bacterial burden in pulmonary tuberculosis. Int J Tuberc Lung Dis (2017) 21(1):93-9. doi:10.5588/ijtld.16.0565

84. Chun RF, Adams JS, Hewison M. Immunomodulation by vitamin D: implications for TB. Expert Rev Clin Pharmacol (2011) 4(5):583-91. doi:10.1586/ ecp.11.41

85. Estrella JL, Kan-Sutton C, Gong X, Rajagopalan M, Lewis DE, Hunter RL, et al. A novel in vitro human macrophage model to study the persistence of Mycobacterium tuberculosis using vitamin $\mathrm{D}(3)$ and retinoic acid activated THP-1 macrophages. Front Microbiol (2011) 2:67. doi:10.3389/ fmicb.2011.00067

86. Martineau AR, Newton SM, Wilkinson KA, Kampmann B, Hall BM, Nawroly N, et al. Neutrophil-mediated innate immune resistance to mycobacteria. J Clin Invest (2007) 117(7):1988-94. doi:10.1172/JCI31097

87. Corrales-Garcia L, Ortiz E, Castaneda-Delgado J, Rivas-Santiago B, Corzo G. Bacterial expression and antibiotic activities of recombinant variants of human beta-defensins on pathogenic bacteria and M. tuberculosis. Protein Expr Purif (2013) 89(1):33-43. doi:10.1016/j.pep.2013.02.007

88. Rivas-Santiago B, Rivas Santiago CE, Castaneda-Delgado JE, LeonContreras JC, Hancock RE, Hernandez-Pando R. Activity of LL-37, CRAMP and antimicrobial peptide-derived compounds E2, E6 and CP26 against Mycobacterium tuberculosis. Int J Antimicrob Agents (2013) 41(2):143-8. doi:10.1016/j.ijantimicag.2012.09.015

89. Bacchetta J, Zaritsky JJ, Sea JL, Chun RF, Lisse TS, Zavala K, et al. Suppression of iron-regulatory hepcidin by vitamin D. JAm Soc Nephrol (2014) 25(3):564-72. doi:10.1681/ASN.2013040355

90. Salamon H, Bruiners N, Lakehal K, Shi L, Ravi J, Yamaguchi KD, et al. Cutting edge: vitamin D regulates lipid metabolism in Mycobacterium tuberculosis infection. J Immunol (2014) 193(1):30-4. doi:10.4049/jimmunol. 1400736

91. Nursyam EW, Amin Z, Rumende CM. The effect of vitamin D as supplementary treatment in patients with moderately advanced pulmonary tuberculous lesion. Acta Med Indones (2006) 38(1):3-5.

92. Wejse C, Gomes VF, Rabna P, Gustafson P, Aaby P, Lisse IM, et al. Vitamin D as supplementary treatment for tuberculosis: a double-blind, randomized, placebo-controlled trial. Am J Respir Crit Care Med (2009) 179(9):843-50. doi:10.1164/rccm.200804-567OC

93. Martineau AR, Timms PM, Bothamley GH, Hanifa Y, Islam K, Claxton AP, et al. High-dose vitamin $\mathrm{D}(3)$ during intensive-phase antimicrobial treatment of pulmonary tuberculosis: a double-blind randomised controlled trial. Lancet (2011) 377(9761):242-50. doi:10.1016/ S0140-6736(10)61889-2

94. Mily A, Rekha RS, Kamal SM, Akhtar E, Sarker P, Rahim Z, et al. Oral intake of phenylbutyrate with or without vitamin D3 upregulates the cathelicidin LL-37 in human macrophages: a dose finding study for treatment of tuberculosis. BMC Pulm Med (2013) 13:23. doi:10.1186/1471-2466-13-23

95. Marks PA, Richon VM, Miller T, Kelly WK. Histone deacetylase inhibitors. Adv Cancer Res (2004) 91:137-68. doi:10.1016/S0065-230X(04)91004-4

96. Steinmann J, Halldorsson S, Agerberth B, Gudmundsson GH. Phenylbutyrate induces antimicrobial peptide expression. Antimicrob Agents Chemother (2009) 53(12):5127-33. doi:10.1128/AAC.00818-09

97. Mily A, Rekha RS, Kamal SM, Arifuzzaman AS, Rahim Z, Khan L, et al. Significant effects of oral phenylbutyrate and vitamin D3 adjunctive therapy in pulmonary tuberculosis: a randomized controlled trial. PLoS One (2015) 10(9):e0138340. doi:10.1371/journal.pone.0138340

98. Campbell GR, Spector SA. Hormonally active vitamin D3 (1alpha,25dihydroxycholecalciferol) triggers autophagy in human macrophages that inhibits HIV-1 infection. J Biol Chem (2011) 286(21):18890-902. doi:10.1074/jbc.M110.206110

99. Salahuddin N, Ali F, Hasan Z, Rao N, Aqeel M, Mahmood F. Vitamin D accelerates clinical recovery from tuberculosis: results of the SUCCINCT Study [Supplementary Cholecalciferol in recovery from tuberculosis]. A randomized, placebo-controlled, clinical trial of vitamin D supplementation in patients with pulmonary tuberculosis. BMC Infect Dis (2013) 13:22. doi:10.1186/1471-2334-13-22

100. TukvadzeN,SanikidzeE, KipianiM,HebbarG,EasleyKA,ShenviN, etal.Highdose vitamin D3 in adults with pulmonary tuberculosis: a double-blind randomized controlled trial. Am J Clin Nutr (2015) 102(5):1059-69. doi:10.3945/ ajcn.115.113886

101. Mayanja-Kizza H, Jones-Lopez E, Okwera A, Wallis RS, Ellner JJ, Mugerwa $\mathrm{RD}$, et al. Immunoadjuvant prednisolone therapy for HIVassociated tuberculosis: a phase 2 clinical trial in Uganda. J Infect Dis (2005) 191(6):856-65. doi:10.1086/427995

102. Wallis RS. Corticosteroid effects on sputum culture in pulmonary tuberculosis: a meta-regression analysis. Open Forum Infect Dis (2014) 1(1):ofu020. doi:10.1093/ofid/ofu020

103. Thwaites GE, Nguyen DB, Nguyen HD, Hoang TQ, Do TT, Nguyen TC, et al. Dexamethasone for the treatment of tuberculous meningitis in adolescents and adults. N Engl J Med (2004) 351(17):1741-51. doi:10.1056/ NEJMoa040573

104. Condos R, Rom WN, Schluger NW. Treatment of multidrug-resistant pulmonary tuberculosis with interferon-gamma via aerosol. Lancet (1997) 349(9064):1513-5. doi:10.1016/S0140-6736(96)12273-X

105. Koh WJ, Kwon OJ, Suh GY, Chung MP, Kim H, Lee NY, et al. Six-month therapy with aerosolized interferon-gamma for refractory multidrugresistant pulmonary tuberculosis. J Korean Med Sci (2004) 19(2):167-71. doi:10.3346/jkms.2004.19.2.167

106. Giosue S, Casarini M, Ameglio F, Zangrilli P, Palla M, Altieri AM, et al. Aerosolized interferon-alpha treatment in patients with multi-drugresistant pulmonary tuberculosis. Eur Cytokine Netw (2000) 11(1):99-104.

107. Johnson JL, Ssekasanvu E, Okwera A, Mayanja H, Hirsch CS, Nakibali JG, et al. Randomized trial of adjunctive interleukin-2 in adults with pulmonary tuberculosis. Am J Respir Crit Care Med (2003) 168(2):185-91. doi:10.1164/rccm.200211-1359OC

108. Shen H, Min R, Tan Q, Xie W, Wang H, Pan H, et al. The beneficial effects of adjunctive recombinant human interleukin-2 for multidrug resistant tuberculosis. Arch Med Sci (2015) 11(3):584-90. doi:10.5114/aoms.2015.52362

109. Deluca HF, Cantorna MT. Vitamin D: its role and uses in immunology. FASEB J (2001) 15(14):2579-85. doi:10.1096/f.01-0433rev

110. Vidyarani M, Selvaraj P, Jawahar MS, Narayanan PR. 1, 25 dihydroxyvitamin D3 modulated cytokine response in pulmonary tuberculosis. Cytokine (2007) 40(2):128-34. doi:10.1016/j.cyto.2007.08.005

111. Selvaraj P, Harishankar M, Singh B, Banurekha VV, Jawahar MS. Effect of vitamin D3 on chemokine expression in pulmonary tuberculosis. Cytokine (2012) 60(1):212-9. doi:10.1016/j.cyto.2012.06.238

112. Harishankar M, Afsal K, Banurekha VV, Meenakshi N, Selvaraj P. 1,25dihydroxy vitamin D3 downregulates pro-inflammatory cytokine response in pulmonary tuberculosis. Int Immunopharmacol (2014) 23(1):148-52. doi:10.1016/j.intimp.2014.08.021

113. Chandra G, Selvaraj P, Jawahar MS, Banurekha VV, Narayanan PR. Effect of vitamin D3 on phagocytic potential of macrophages with live Mycobacterium tuberculosis and lymphoproliferative response in pulmonary tuberculosis. J Clin Immunol (2004) 24(3):249-57. doi:10.1023/B: JOCI.0000025446.44146.52

114. Matsuzaki J, Tsuji T, Zhang Y, Wakita D, Imazeki I, Sakai T, et al. 1alpha,25Dihydroxyvitamin D3 downmodulates the functional differentiation of Th1 cytokine-conditioned bone marrow-derived dendritic cells beneficial for cytotoxic T lymphocyte generation. Cancer Sci (2006) 97(2):139-47. doi:10.1111/j.1349-7006.2006.00144.x

115. Prabhu Anand S, Selvaraj P, Narayanan PR. Effect of 1,25 dihydroxyvitamin D3 on intracellular IFN-gamma and TNF-alpha positive T cell subsets in pulmonary tuberculosis. Cytokine (2009) 45(2):105-10. doi:10.1016/j. cyto.2008.11.004

116. Penna G, Amuchastegui S, Giarratana N, Daniel KC, Vulcano M, Sozzani S, et al. 1,25-dihydroxyvitamin D3 selectively modulates tolerogenic properties in myeloid but not plasmacytoid dendritic cells. JImmunol (2007) 178(1):145-53. doi:10.4049/jimmunol.178.1.145

117. Nielsen NO, Skifte T, Andersson M, Wohlfahrt J, Soborg B, Koch A, et al. Both high and low serum vitamin D concentrations are associated with tuberculosis: a case-control study in Greenland. Br J Nutr (2010) 104(10): 1487-91. doi:10.1017/S0007114510002333 
118. Bento CF, Empadinhas N, Mendes V. Autophagy in the fight against tuberculosis. DNA Cell Biol (2015) 34(4):228-42. doi:10.1089/dna.2014.2745

119. Jo EK. Autophagy as an innate defense against mycobacteria. Pathog Dis (2013) 67(2):108-18. doi:10.1111/2049-632X.12023

120. Watson RO, Manzanillo PS, Cox JS. Extracellular M. tuberculosis DNA targets bacteria for autophagy by activating the host DNA-sensing pathway. Cell (2012) 150(4):803-15. doi:10.1016/j.cell.2012.06.040

121. Ravikumar B, Vacher C, Berger Z, Davies JE, Luo S, Oroz LG, et al. Inhibition of mTOR induces autophagy and reduces toxicity of polyglutamine expansions in fly and mouse models of Huntington disease. Nat Genet (2004) 36(6):585-95. doi:10.1038/ng1362

122. Munz C. Enhancing immunity through autophagy. Annu Rev Immunol (2009) 27:423-49. doi:10.1146/annurev.immunol.021908.132537

123. Coussens AK, Martineau AR, Wilkinson RJ. Anti-inflammatory and antimicrobial actions of vitamin D in combating TB/HIV. Scientifica (Cairo) (2014) 2014:903680. doi:10.1155/2014/903680

124. Fowler CJ. NSAIDs: eNdocannabinoid stimulating anti-inflammatory drugs? Trends Pharmacol Sci (2012) 33(9):468-73. doi:10.1016/j.tips.2012.05.003

125. Tonby K, Wergeland I, Lieske NV, Kvale D, Tasken K, Dyrhol-Riise AM. The COX- inhibitor indomethacin reduces Thl effector and T regulatory cells in vitro in Mycobacterium tuberculosis infection. BMC Infect Dis (2016) 16(1):599. doi:10.1186/s12879-016-1938-8

126. Basil MC, Levy BD. Specialized pro-resolving mediators: endogenous regulators of infection and inflammation. Nat Rev Immunol (2016) 16(1):51-67. doi:10.1038/nri.2015.4

127. Berger W, De Chandt MT, Cairns CB. Zileuton: clinical implications of 5-lipoxygenase inhibition in severe airway disease. Int J Clin Pract (2007) 61(4):663-76. doi:10.1111/j.1742-1241.2007.01320.x

128. Remmelts HH, Meijvis SC, Biesma DH, van Velzen-Blad H, Voorn GP, Grutters JC, et al. Dexamethasone downregulates the systemic cytokine response in patients with community-acquired pneumonia. Clin Vaccine Immunol (2012) 19(9):1532-8. doi:10.1128/CVI.00423-12

129. Kadhiravan T, Deepanjali S. Role of corticosteroids in the treatment of tuberculosis: an evidence-based update. Indian J Chest Dis Allied Sci (2010) 52(3):153-8.

130. Critchley JA, Young F, Orton L, Garner P. Corticosteroids for prevention of mortality in people with tuberculosis: a systematic review and meta-analysis. Lancet Infect Dis (2013) 13(3):223-37. doi:10.1016/S1473-3099(12)70321-3

131. Prasad K, Singh MB. Corticosteroids for managing tuberculous meningitis. Cochrane Database Syst Rev (2008) 1:CD002244. doi:10.1002/14651858. CD002244.pub3

132. Mayosi BM, Ntsekhe M, Volmink JA, Commerford PJ. Interventions for treating tuberculous pericarditis. Cochrane Database Syst Rev (2002) 4:CD000526. doi:10.1002/14651858.CD000526

133. Tuberculosis Research, Centre. Study of chemotherapy regimens of 5 and 7 months' duration and the role of corticosteroids in the treatment of sputum-positive patients with pulmonary tuberculosis in South India. Tubercle (1983) 64(2):73-91. doi:10.1016/0041-3879(83)90032-6

134. Muthuswamy P, Hu TC, Carasso B, Antonio M, Dandamudi N. Prednisone as adjunctive therapy in the management of pulmonary tuberculosis. Report of 12 cases and review of the literature. Chest (1995) 107(6):1621-30. doi:10.1378/chest.107.6.1621

135. Maurice DH, Ke H, Ahmad F, Wang Y, Chung J, Manganiello VC. Advances in targeting cyclic nucleotide phosphodiesterases. Nat Rev Drug Discov (2014) 13(4):290-314. doi:10.1038/nrd4228

136. Subbian S, Tsenova L, O'Brien P, Yang G, Koo MS, Peixoto B, et al. Phosphodiesterase-4 inhibition alters gene expression and improves isoniazid-mediated clearance of Mycobacterium tuberculosis in rabbit lungs. PLoS Pathog (2011) 7(9):e1002262. doi:10.1371/journal.ppat.1002262

137. Subbian S, Tsenova L, O'Brien P, Yang G, Koo MS, Peixoto B, et al. Phosphodiesterase-4 inhibition combined with isoniazid treatment of rabbits with pulmonary tuberculosis reduces macrophage activation and lung pathology. Am J Pathol (2011) 179(1):289-301. doi:10.1016/j.ajpath. 2011.03.039

138. Maiga M, Agarwal N, Ammerman NC, Gupta R, Guo H, Maiga MC, et al. Successful shortening of tuberculosis treatment using adjuvant host-directed therapy with FDA-approved phosphodiesterase inhibitors in the mouse model. PLoS One (2012) 7(2):e30749. doi:10.1371/journal. pone. 0030749

139. Elkington PT, Ugarte-Gil CA, Friedland JS. Matrix metalloproteinases in tuberculosis. Eur Respir J (2011) 38(2):456-64. doi:10.1183/09031936. 00015411

140. Elkington PT, D’Armiento JM, Friedland JS. Tuberculosis immunopathology: the neglected role of extracellular matrix destruction. Sci Transl Med (2011) 3(71):71s76. doi:10.1126/scitranslmed.3001847

141. Ong CW, Elkington PT, Brilha S, Ugarte-Gil C, Tome-Esteban MT, Tezera LB, et al. Neutrophil-derived MMP-8 drives AMPK-dependent matrix destruction in human pulmonary tuberculosis. PLoS Pathog (2015) 11(5):e1004917. doi:10.1371/journal.ppat.1004917

142. Cooper AM. Cell-mediated immune responses in tuberculosis. Annu Rev Immunol (2009) 27:393-422. doi:10.1146/annurev.immunol.021908. 132703

143. Edwards JE, Moore RA. Statins in hypercholesterolaemia: a dosespecific meta-analysis of lipid changes in randomised, double blind trials. BMC Fam Pract (2003) 4:18. doi:10.1186/1471-2296-4-18

144. Mortensen EM, Restrepo MI, Anzueto A, Pugh J. The effect of prior statin use on 30-day mortality for patients hospitalized with communityacquired pneumonia. Respir Res (2005) 6:82. doi:10.1186/1465-9921-6-82

145. Thomsen RW, Hundborg HH, Johnsen SP, Pedersen L, Sorensen HT, Schonheyder HC, et al. Statin use and mortality within 180 days after bacteremia: a population-based cohort study. Crit Care Med (2006) 34(4):1080-6. doi:10.1097/01.CCM.0000207345.92928.E4

146. Kwak B, Mulhaupt F, Myit S, Mach F. Statins as a newly recognized type of immunomodulator. Nat Med (2000) 6(12):1399-402. doi:10.1038/ 82219

147. Kang YA, Choi NK, Seong JM, Heo EY, Koo BK, Hwang SS, et al. The effects of statin use on the development of tuberculosis among patients with diabetes mellitus. Int J Tuberc Lung Dis (2014) 18(6):717-24. doi:10.5588/ ijtld.13.0854

148. Lai CC, Lee MT, Lee SH, Hsu WT, Chang SS, Chen SC, et al. Statin treatment is associated with a decreased risk of active tuberculosis: an analysis of a nationally representative cohort. Thorax (2016) 71(7):646-51. doi:10.1136/ thoraxjnl-2015-207052

149. van der Windt GJ, Everts B, Chang CH, Curtis JD, Freitas TC, Amiel E, et al. Mitochondrial respiratory capacity is a critical regulator of CD8+ T cell memory development. Immunity (2012) 36(1):68-78. doi:10.1016/j.immuni.2011.12.007

150. Singh NP, Hegde VL, Hofseth LJ, Nagarkatti M, Nagarkatti P. Resveratrol (trans-3,5,4'-trihydroxystilbene) ameliorates experimental allergic encephalomyelitis, primarily via induction of apoptosis in $\mathrm{T}$ cells involving activation of aryl hydrocarbon receptor and estrogen receptor. Mol Pharmacol (2007) 72(6):1508-21. doi:10.1124/mol.107.038984

151. Dilek N, Poirier N, Hulin P, Coulon F, Mary C, Ville S, et al. Targeting CD28, CTLA-4 and PD-L1 costimulation differentially controls immune synapses and function of human regulatory and conventional T-cells. PLoS One (2013) 8(12):e83139. doi:10.1371/journal.pone.0083139

152. Niezgoda A, Niezgoda P, Czajkowski R. Novel approaches to treatment of advanced melanoma: a review on targeted therapy and immunotherapy. Biomed Res Int (2015) 2015:851387. doi:10.1155/2015/851387

153. He Y, Rivard CJ, Rozeboom L, Yu H, Ellison K, Kowalewski A, et al. Lymphocyte-activation gene-3, an important immune checkpoint in cancer. Cancer Sci (2016) 107(9):1193-7. doi:10.1111/cas.12986

154. Phillips BL, Mehra S, Ahsan MH, Selman M, Khader SA, Kaushal D. LAG3 expression in active Mycobacterium tuberculosis infections. Am J Pathol (2015) 185(3):820-33. doi:10.1016/j.ajpath.2014.11.003

155. O’Reilly RJ, Doubrovina E, Trivedi D, Hasan A, Kollen W, Koehne G. Adoptive transfer of antigen-specific T-cells of donor type for immunotherapy of viral infections following allogeneic hematopoietic cell transplants. Immunol Res (2007) 38(1-3):237-50. doi:10.1007/s12026-007-0059-2

156. Brenner MK, Heslop HE. Adoptive T cell therapy of cancer. Curr Opin Immunol (2010) 22(2):251-7. doi:10.1016/j.coi.2010.01.020

157. Parida SK, Madansein R, Singh N, Padayatchi N, Master I, Naidu K, et al. Cellular therapy in tuberculosis. Int J Infect Dis (2015) 32:32-8. doi:10.1016/j.ijid.2015.01.016 
158. Parida SK, Poiret T, Zhenjiang L, Meng Q, Heyckendorf J, Lange C, et al. T-cell therapy: options for infectious diseases. Clin Infect Dis (2015) 61(Suppl 3):S217-24. doi:10.1093/cid/civ615

159. Flynn JL, Chan J, Triebold KJ, Dalton DK, Stewart TA, Bloom BR. An essential role for interferon gamma in resistance to Mycobacterium tuberculosis infection. J Exp Med (1993) 178(6):2249-54. doi:10.1084/jem. 178.6.2249

160. Reljic R. IFN-gamma therapy of tuberculosis and related infections. J Interferon Cytokine Res (2007) 27(5):353-64. doi:10.1089/jir.2006.0103

161. Suter-Riniker F, Berger A, Mayor D, Bittel P, Iseli P, Bodmer T. Clinical significance of interleukin-2/gamma interferon ratios in Mycobacterium tuberculosis-specific T-cell signatures. Clin Vaccine Immunol (2011) 18(8): 1395-6. doi:10.1128/CVI.05013-11

162. Jacobs AJ, Mongkolsapaya J, Screaton GR, McShane H, Wilkinson RJ. Antibodies and tuberculosis. Tuberculosis (Edinb) (2016) 101:102-13. doi:10.1016/j.tube.2016.08.001

163. Kozakiewicz L, Chen Y, Xu J, Wang Y, Dunussi-Joannopoulos K, Ou Q, et al. B cells regulate neutrophilia during Mycobacterium tuberculosis infection and BCG vaccination by modulating the interleukin-17 response. PLoS Pathog (2013) 9(7):e1003472. doi:10.1371/journal.ppat.1003472

164. Maglione PJ, Xu J, Casadevall A, Chan J. Fc gamma receptors regulate immune activation and susceptibility during Mycobacterium tuberculosis infection. J Immunol (2008) 180(5):3329-38. doi:10.4049/jimmunol.180.5.3329

165. Guilliams M, Bruhns P, Saeys Y, Hammad H, Lambrecht BN. The function of Fcgamma receptors in dendritic cells and macrophages. Nat Rev Immunol (2014) 14(2):94-108. doi:10.1038/nri3582
166. de Valliere S, Abate G, Blazevic A, Heuertz RM, Hoft DF. Enhancement of innate and cell-mediated immunity by antimycobacterial antibodies. Infect Immun (2005) 73(10):6711-20. doi:10.1128/IAI.73.10.6711-6720.2005

167. Kumar SK, Singh P, Sinha S. Naturally produced opsonizing antibodies restrict the survival of Mycobacterium tuberculosis in human macrophages by augmenting phagosome maturation. Open Biol (2015) 5(12):150171. doi:10.1098/rsob.150171

168. Olivares N, Puig A, Aguilar D, Moya A, Cadiz A, Otero O, et al. Prophylactic effect of administration of human gamma globulins in a mouse model of tuberculosis. Tuberculosis (Edinb) (2009) 89(3):218-20. doi:10.1016/j. tube.2009.02.003

169. Achkar JM, Casadevall A. Antibody-mediated immunity against tuberculosis: implications for vaccine development. Cell Host Microbe (2013) 13(3):250-62. doi:10.1016/j.chom.2013.02.009

Conflict of Interest Statement: The authors declare that the research was conducted in the absence of any commercial or financial relationships that could be construed as a potential conflict of interest.

Copyright (c) 2017 Kolloli and Subbian. This is an open-access article distributed under the terms of the Creative Commons Attribution License (CC BY). The use, distribution or reproduction in other forums is permitted, provided the original author(s) or licensor are credited and that the original publication in this journal is cited, in accordance with accepted academic practice. No use, distribution or reproduction is permitted which does not comply with these terms. 